IRREGULAR MIGRATION AS A CHALLENGE FOR DEMOCRACY 


\section{European Integration and Democracy Series}

Editor-in-Chief

ELŻBIETA KUŻELEWSKA, University of Białystok, Poland

Series Editors

DANIEL BARNHIZER, Michigan State University, East Lansing MI, United States of America

TOMAS BERKMANAS, Vytautas Magnus University, Kaunas, Lithuania FILIP KŘEPELKA, Masaryk University, Brno, Czech Republic ERICH SCHWEIGHOFER, University of Vienna, Austria RYSZARD SKARZYŃSKI, University of Białystok, Poland KONSTANTY A. WOJTASZCZYK, University of Warsaw, Poland 


\title{
IRREGULAR MIGRATION AS A CHALLENGE FOR DEMOCRACY
}

\author{
Edited by \\ Elżbieta KużELEWSKA \\ Amy Weatherburn \\ Dariusz KlozA
}

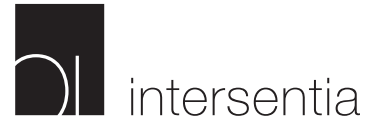

Cambridge - Antwerp - Portland 


\section{Intersentia Ltd}

Sheraton House | Castle Park

Cambridge | CB3 0AX | United Kingdom

Tel.: +441223 370170 | Fax: +44 1223370169

Email: mail@intersentia.co.uk

www.intersentia.com | www.intersentia.co.uk

Distribution for the UK and Ireland:

NBN International

Airport Business Centre, 10 Thornbury Road

Plymouth, PL6 7PP

United Kingdom

Tel.: +441752202301 | Fax: +44 1752202331

Email: orders@nbninternational.com

Distribution for Europe and all other countries:

Intersentia Publishing nv

Groenstraat 31

2640 Mortsel

Belgium

Tel.: +32 36801550 | Fax: +3236587121

Email: mail@intersentia.be

Distribution for the USA and Canada:

International Specialized Book Services

920 NE 58th Ave. Suite 300

Portland, OR 97213

USA

Tel.: +1 8009446190 (toll free) | Fax: +1 5032808832

Email: info@isbs.com

\section{Irregular Migration as a Challenge for Democracy}

(C) The editors and contributors severally 2018

The editors and contributors have asserted the right under the Copyright, Designs and Patents Act 1988, to be identified as authors of this work.

No part of this book may be reproduced, stored in a retrieval system, or transmitted, in any form, or by any means, without prior written permission from Intersentia, or as expressly permitted by law or under the terms agreed with the appropriate reprographic rights organisation. Enquiries concerning reproduction which may not be covered by the above should be addressed to Intersentia at the address above.

Artwork on the cover:

Jeffrey Smart (Italy; Australia, b.1921, d.2013)

Bus terminus (1973)

synthetic polymer paint and oil on canvas, $92 \times 81 \mathrm{~cm}$

Art Gallery of New South Wales

Bequest of Mrs John Minter 1998

Photo: Brenton McGeachie, AGNSW

(C) Estate of Jeffrey Smart

251.1998

ISBN 978-1-78068-622-6

D/2018/7849/35

NUR 828

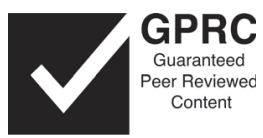

British Library Cataloguing in Publication Data. A catalogue record for this book is available from the British Library. 


\title{
FOREWORD
}

\section{European Responses to Immigration - and its Critics: Democratic Dilemmas}

\author{
Kristian BERg HARPVIKEN*
}

Immigration has emerged as the defining issue of our times. Across the democratic states of Europe, there is deep resistance to immigration. From the vantage point of late 2017, it is hard to think of a topic more in need of analysis and understanding than the tensions between democracy and migration, so eloquently shed light on by the contributors to this volume, which brings together a wide spectrum of disciplinary and analytical perspectives. The editors deserve praise for their initiative - even courage - in taking on this topic, which is as pressing as it is delicate, raising dilemmas that can only be met through intellectual and ethical honesty. I am grateful to the authors and the editors alike, and I am honoured to be asked to contribute with the foreword.

The 2015 'migration crisis' has become a major reference point in European politics. The nature of the 'crisis' is contested. Some see the 'crisis' as the onset of a new era of mass migration, others emphasise the failure of international migration management. In either case, across Europe, we see the emergence of a strong anti-immigration movement. Relatedly, we see mounting polarisation within states and mounting scepticism to existent political elites, even to the way democracy works. We have become accustomed to take democratic progress for granted, but we may find ourselves on the verge of what late Charles Tilly would call 'de-democratization' ${ }^{1}$ - a process where there is decreasing equality between state agents and citizens, where binding political consultation (state-citizens) is fading, and where protection of the population (particularly minorities) from arbitrary action by government agents is weakening. Are we entering an era of de-democratisation? The question is tied to the future of the European project

Peace Research Institute Oslo (PRIO), Norway. E-mail: kristian@prio.org.

C. Tilly, Democracy, Cambridge University Press, Cambridge 2007, p. 13. 
itself, where deepening dissatisfaction with the European Union both divides the citizenry of its Member States and creates deep rifts between Member States. The future of European integration and the future of democracy in Europe are intrinsically connected, with immigration as the central issue of contestation.

Anti-immigration sentiments in Europe have grown steadily at least since the 1970s. It has taken various expressions, from violent attacks (on immigrants, asylum centres or various care-takers) to regular parliamentary debates. Quite remarkably, anti-immigration has come to the fore in countries that differ fundamentally both in their policies and in the degrees and forms of immigration they have experienced. Poland, to take one example, is one of the most homogenous countries in Europe, yet anti-immigration has been a central mobilising issue and contributed to parliamentary majority for the Law and Justice Party, which pursues a very restrictive immigration policy, at odds with Brussels. Germany, which for decades has pursued perhaps the most generous immigration policy in Europe, and whose population is multi-cultural, sees similar sentiments, well beyond the support base of the Alternative für Deutschland (AfD), the party that landed 12.6 per cent of the vote in the 2017 national elections.

'Resistance against migration is the clearly most important cleavage line to appear in ... European politics', argues Norwegian sociologist Lars Mjøset. ${ }^{2}$ If so, it is quite remarkable how adaptable this movement is to various national contexts. It is equally remarkable, as Mjøset points out, that this is a movement that does not first and foremost take the shape of separate singleissue organisations - the ghost of national socialism has effectively prevented that - but, rather, the issue is picked up by political entrepreneurs tied to parties, often populist, largely on the right (although traditional labour milieus are not exempted). Anti-immigration sentiments, in most countries, have wide appeal and are also picked up by mainstream parties who seek to meet the threat from the political right by variations over the theme of being 'tough on immigration'.

It was the 2015 upsurge of immigrant arrivals to Europe - a large share being asylum seekers from Syria, followed by Eritrea and Afghanistan - that definitively brought the immigration debate to the top of the list of political priorities in most European countries. The 2017 Eurobarometer reveals that whereas terrorism is seen by most as the chief concern ( 44 per cent, up 12 per cent over the last year), immigration follows suit (with 38 per cent,

L. Mjøset, 'Old and New Social Movements in the Nordic Countries - History and Future in an International Perspective' in F. Engelstad, C. Holst and G.C. AakvaAg (eds.), Democratic State and Democratic Society, De Gruyter, Berlin 2018 (forthcoming). 
down 7 per cent since 2016). These two issues dominate, with the topmost other issue being the economic situation, listed by 18 per cent. Climate change and the environment, are listed by, respectively, 8 per cent and 6 per cent, even though these issues are spearheaded by strong social movements, and are seen by many experts as threats of enormous magnitude in the longer term. ${ }^{3}$

The concerns of immigration sceptics were well known, but carried a different weight in 2015, with seemingly unstoppable mass arrivals, and a corresponding collapse in the institutions set up for migration management, particularly those at the European level. Many, but not all, of the concerns focus on Muslim immigrants. The sense of a threat to culture and values is prominent (and, parenthetically, may also take the form of a worry about the future of democracy, with new citizens coming from non-democratic states where there has been little reason to trust the institutions of power). Equally, some worry about the distribution of economic resources, as immigrants will need support (at least in the short term), in a climate where mechanisms of welfare and redistribution are already scaled back in many European countries. Security is another concern, exacerbated by an increase in the number of terror attacks in Europe and the 'foreign fighters' who have travelled to Syria to join violent extremist groups.

A dilemma - particularly for countries that already host large immigrant populations - is that the new policies adopted in order to prevent future large-scale immigration may be exacerbating problems within. Policies aimed at deterring immigration may make integration more difficult for those already here. Ultimately, policies aimed at constraining immigration may bring about exclusion, with the inherent risk that at least some immigrants turn to extremism, even violence, fulfilling the basic prophecy of immigrants as security threats. This is seen clearly when domestic integration programmes are revised, in part with a view to send a strong message to prospective immigrants that this is not a 'welcoming' country. Likewise, when strong messaging is used in media campaigns to deter prospective migrants, the message is picked up by those who are already accepted, who unavoidably feel less welcome. This relates to a broader concern over a possibly deepening cleavage between the majority population and groups of immigrants of non-Western origin.

In this book, however, the main interest is in the broader polarization we see in virtually all European states, with increasingly recalcitrant positions dividing the citizenry, and with immigration as the issue that crystallises the conflict. Norway, which has been ruled by a minority coalition of the Conservatives and the Progress Party since 2013 (a mandate renewed in the parliamentary

European Commission, 'Public Opinion in the European Union', Standard Eurobarometer 87, Brussels 2017, <http://ec.europa.eu/commfrontoffice/publicopinion/index.cfm/ResultDoc/ download/DocumentKy/79565> accessed 19.03.2018. 
elections in September 2017), is a case in point. The Progress Party, definitely at the moderate end among right-wing populist parties in Europe, pursues a strict immigration policy. The party has gained from it, so much so that other more mainstream parties are reluctant to challenge its views, with the net effect being a tangible shift on immigration policy overall. One element, amongst many, has been a grand push to return asylum-seekers who have not been granted a right to stay. An Amnesty International report from October 2017 pinpoints Norway as the country in Europe that returns the highest number of Afghans, in absolute numbers. ${ }^{4}$ Asylum-seekers under 18 , who would not receive appropriate care upon return, are being granted temporary protection, but are deported upon their eighteenth birthday. Since 2016 the Norwegian government has been working to open an orphanage in Kabul to enable the return of minors without care. The deputy minister for justice and public security at the time, Jøran Kallmyr, argued that:

[m]any of those who come to Norway do so for economic reasons. If we have a consistent practice, where it is the basis for asylum that counts, there will be fewer who are sent on a dangerous trip to Europe. The families and kids will not achieve the goal of obtaining money. ${ }^{5}$

There have been strong negative reactions to these strict return measures from citizens in most parts of the political spectrum. Norway, where the relative consensus on most major issues has been so deep that this has often been pointed to as a problem, is an interesting case. Over the early parts of the twenty-first century, we see that consensus being challenged - with immigration as the issue where political emotions run the highest, and polarization goes the deepest.

Accommodating the anti-immigration movement through conventional politics is a challenge in its own right. Mjøset, with reference to Beck's conceptualisation of political mobilisation in 'risk society', ${ }^{6}$ points out that whereas the political movements of the industrial area were offensive and focused on issues that could be addressed within the confines of the nation-state, the movements of the current times are fundamentally defensive and address issues that necessitate transnational solutions. ${ }^{7}$ The labour movement, or the

4 Amnesty International, Forced back to Danger: Asylum-seekers returned from Europe to Afghanistan, London 2017, <https://www.amnesty.org/en/documents/asa11/6866/2017/en> accessed 19.03.2018.

5 T. Strand and S. Granviken, 'Norge vil sende afghanske gutter til barnehjem i Kabul: Afghanistan er positiv' [Norway would like to send Afghan boys to an orphanage in Kabul. Afghanistan is positive], Aftenposten, 01.02.2016, <https://www.aftenposten.no/norge/i/ z7dw/Norge-vil-sende-afghanske-gutter-til-barnehjem-i-Kabul-Afghanistan-er-positiv> accessed 19.03.2018 (author's translation).

$6 \quad$ U. Beck, Risk Society: Towards a New Modernity, Sage, London 1992.

7 L. MJøset, supra n. 2. 
women's rights movement, to take two examples of the industrial era, both had proactive claims, which could be addressed through a variety of institutional innovations and political reforms at a national level. The movements of the present, of which anti-immigration is one example (other examples are anti-globalisation and environmental activism) are defensive - fighting to constrain a strong irreversible trend - and they engage with issues that fundamentally can only be managed through international cooperation. The uncomfortable paradox is evident for anti-immigration, which almost always goes hand in hand with a deep scepticism of supranational institutions, rooted in nationalism of some sort or another, and thereby undermines the very institutions that are so critical to managing the movement's main political concerns.

The polarisation within Europe's nation-states has its parallel in mounting tensions between those states, creating a deep rift within the Union itself. To the surprise of most observers, the Euro-crisis, serious as its after-effects are, was superseded by the 2015 migration crisis, which brought to light a deep political-cultural divide between the West and the East, between Old and New Europe. The Euro-crisis, no doubt, was a fundamental challenge, with countries of the Mediterranean (Greece and Cyprus in particular) pitted against Northern Europe. Germany spearheaded structural responses, widely unpopular further South, but stood out as the undisputed leader that saved the European project. The migration crisis, at first sight far less of a threat, proved to be the opposite. Germany received much of the blame for the immigration wave, given its generous welcome, and as an already reluctant leader of Europe, it lost legitimacy. While the South-North divide is also relevant for immigration, with the bulk of migrants arriving illegally by sea to Greece and Italy, the main fault line within the Union goes East-West.

The New Europe, argues German sociologist Christian Joppke, is sceptical of immigration in large part because decades under communism have shielded its populations from the liberal revolutions that had transformed the political debate in the capitalist West. Human rights writ large - with the acceptance of religious, ethnic, sexual, and other sorts of difference - has not taken hold. ${ }^{8}$ Hence, writes Joppke, the illiberal Christian nationalism that Hungary's Prime Minister Viktor Orbán preaches is not an exception, but rather a representation of widely held sentiments. When Europe has failed to come up with effective joint responses to migration, the failure has been ultimately rooted in this divide, and for every effort that fails the divide grows wider. The EU's resettlement

8 C. Joppкe, 'The Syrian Refugee Crisis and the Two Europes: Christian Europe \& Liberal Multiculturalism', The Critique, 06.01.2016, <http://www.thecritique.com/articles/the-syrianrefugee-crisis-the-two-europes-5> accessed 14.11.2017. 
scheme, for example, adopted against the loud protests of many of the EU's newest members, has proven virtually impossible to implement, and Brussels is at risk of exacerbating the problem as it moves towards imposing the scheme, penalising countries that resist. In this there is a painful irony, as the measures that have proven most effective in halting immigration to Europe - the border fences of Hungary, the naval policing of the Aegean Sea, the internment camps in Libya - are fundamentally at odds with the very values celebrated by the liberals of Old Europe.

But can the immigration challenge fundamentally threaten democracy in Europe? As should be clear from the discussion above, I am not here primarily concerned with the issue that new citizens may be lacking an understanding of - or respect for - the workings of the democratic state. Even though that is a real concern, it does not seem to me to be one that in its own right threatens democracy, simply because experience teaches us that the absolute bulk of immigrants learn to appreciate the majority's basic values (and for many, this was a major motivation for moving in the first place). No, I am more concerned with the deep rifts within Europe's nation-states, where anti-immigration is the galvanising issue for citizens who otherwise may differ widely in their political opinions, but nonetheless share one or several of the following broad orientations: economic protectionism; anti-elitism; nationalism; dismantling of (old or new) minorities' rights, guarding of traditional family values; and increasing use of force as a tool of governance (both in domestic and foreign affairs). The extent to which these orientations are at odds with basic democracy varies widely some of them need not be so at all - but the totality, if coming together under one political umbrella, alongside anti-immigration, is a prescription for the onset of what Tilly termed 'de-democratization', a process where the binding political consultation between a government and its citizens lose out to other mechanisms of political decision-making and everyday rule. ${ }^{9}$

The challenge that the immigration issue poses to the future of European democracy is real. Immigration itself is a genuine challenge, but the fundamental challenge that immigration brings to the fore is a domestic one, it is about fundamentally different political visions that cut through the citizenry of Europe's nation-states. With that, it becomes critically important how these nation-states, through their democratic institutions, tackle immigration. Writing in the fall of 2017, so far, much of what we have seen is a dramatic shift towards stricter controls, deterrence, restrictions in transit and sending countries, measures also adopted by mainstream parties that not long ago embraced a much more liberal line. All of this, while ethically deeply problematic, is also understandable, not only because of the fear of mass immigration, but also 
because of the fear of a popular reaction that threatens democracy itself. There is undoubtedly a need to develop policies that secure protection for those who need it the most; policies that does not imply a cessation of human mobility as we know it. But ultimately, while tackling immigration is necessary in order to secure continued democratisation of Europe's nation-states, it is not going to be sufficient, simply because the forces of de-democratisation span so much wider, and because once an anti-immigration sentiment is out of the bottle, it is hard to put it back in.

The resistance to supranational decision-making - here, in the form of the European Union - brings the dilemma to the fore. Such resistance is closely associated with the anti-immigration movement. Yet, the immigration itself transcends the borders between nation-states, and cries out for international responses, exactly at a time when European institutions falter, in large part, as a consequence of rifts both between and within its Member States. The fact that the Union struggles to stem political fragmentation, at a time - and on an issue - where a coordinated response is needed is deeply worrisome. In that situation, we need both the scholarly analysis and reflection presented in this volume, and we need informed political innovation within and between Europe's nation-states.

Oslo, October 2017 



\title{
INTRODUCTION
}

\section{Asking Big Questions: Migrants Ante Portas and What to Do with Them?}

\author{
Elżbieta Kużelewska, ${ }^{*}$ Amy Weatherburn ${ }^{* *}$ \\ and Dariusz KLOZA ${ }^{* * *}$
}

'Would you tell me, please, which way I ought to go from here?' 'That depends a good deal on where you want to get to,' said the Cat.

'I don't much care where-' said Alice.

'Then it doesn't matter which way you go,' said the Cat. '-so long as I get somewhere,' Alice added as an explanation. 'Oh, you're sure to do that,' said the Cat, 'if you only walk long enough.' Lewis Carroll, Alice's Adventures in Wonderland $(1865)^{1}$

I.

To what extent does the status quo of irregular migration to Europe pose a challenge for democracy? ${ }^{2}$ The surge of people moving, predominantly from war-torn, repressed and impoverished countries in the Middle East and Africa

* Centre for Direct Democracy Studies (CDDS), Faculty of Law, University of Białystok, Poland. E-mail: ekuzelewska@gmail.com.

** Research Group on Fundamental Rights and Constitutionalism (FRC), Vrije Universiteit Brussel (VUB), Belgium. E-mail: amy.weatherburn@vub.be.

*** Research Group on Law, Science, Technology and Society (LSTS), VUB; Peace Research Institute Oslo (PRIO), Norway. E-mail: dariusz.kloza@vub.be.

1 L. Carroll, Alice's Adventures in Wonderland and Through the Looking-Glass, Random House, New York 2012 [Macmillan, London 1865], pp. 89-90.

2 The International Organization for Migration (IOM) offers definitions for a few key notions concerning migration that we find vital to mention at the outset of our analysis. Starting with the most basic concept, 'migration' is a 'process of moving, either across an international border, or within a State. It is a population movement, encompassing any kind of movement of people, whatever its length, composition and causes; it includes migration of refugees, displaced persons, uprooted people, and economic migrants.' (Semantically speaking, migration is further split into 'immigration', which - according to the Cambridge Dictionary 
to the outer borders of Europe, which started in the early 2010s and which intensified in the summer of 2015 - and the implications for the Old Continent that this massive flow of people has caused - gave an impetus to the present book. It seeks to contribute to the contextualisation, better understanding of and drawing of lessons from the status quo of irregular migration to Europe and its relation to the values and principles on which Europe has been built. ${ }^{3}$

Migration in Europe (i.e. within, to and away from), as anywhere in the world, is by no means a novel phenomenon. ${ }^{4}$ Immigration to the Old Continent once again gained its momentum and - consequently - public attention in the aftermath of the so-called Arab Spring. A sequence of protests against authoritarian political regimes in Africa and the Middle East that broke out on 17 December 2010 in Tunisia resulted in democratisation for some of them, but in others led to political unrest and even civil war. The latter caused an intensified emigration therefrom, largely towards Europe. The Italian island of Lampedusa - located less than $120 \mathrm{~km}$ from the Tunisian shore - and the vessels that have sunk around that island have become symbolic. Lampedusa perhaps marked the first sign that this influx of people constituted a serious problem and hence people started naming it a 'crisis'. Subsequent events only magnified the problem: perhaps the biggest mark has been left by the ongoing Syrian civil war.

In 2015 alone, irregular immigrants filed 1.25 million applications for asylum in the European Union (EU) with a combined total of 68,000 in Norway and Switzerland. ${ }^{5}$ In parallel, an estimated 3,771 lives have been lost or went missing in the Mediterranean in the same year, which increased in the subsequent

of English - is 'the act of someone coming to live in a different country'. 'Emigration' is its antonym, i.e. 'the process of leaving a country in order to live permanently in another country'. A comparable distinction is made between 'immigrants' and 'emigrants.) Migration is irregular if this 'movement ... takes place outside the regulatory norms of the sending, transit and receiving countries'. In turn, 'illegal migration' - a part of irregular one - is often limited to cases of 'smuggling of migrants and trafficking in persons'. Concerning people en route, 'asylum seekers' are those 'seeking to be admitted into a country as refugees and awaiting decision on their application for refugee status'. Asylum seekers are irregular migrants when they do not use regular means to claim the protection they seek. A 'refugee', by contrast, is a person who already received a positive decision on his or her claim for asylum. (We acknowledge these definitions are not legally binding. Such a quality has been vested only e.g. for the definition of a refugee, which we cite infra n. 56.) Cf. IOM, Glossary on Migration, Geneva 2004, <http://www.iomvienna.at/sites/default/files/IML_1_EN.pdf>. All Internet links in this contribution have been verified on 25 November 2017.

3 By 'Europe' we understand a patchwork of economic and political integration processes nowadays taking place on the Old Continent, in particular the European Union (EU). We explain our understanding infra n. 42.

$4 \quad$ Z. Bauman, Strangers at Our Door, Polity Press, Cambridge 2016, p. 3.

5 Eurostat, 'Record number of over 1.2 million first time asylum seekers registered in 2015', press release, 44/2016, 04.03.2016. 
year to $5,022^{6}$ and, as of 25 November 2017, had already reached 2,992. ${ }^{7}$ Europe has faced a situation in which human beings have been fleeing to European soil and a vast majority of them have been seeking - and we are confident this is the right term - some help. (Yet we are aware some of them might come with bad intentions.) As a result, Europe, to its series of recent big questions - for instance, the 'democratic deficit', the rejected 2004 Treaty establishing a Constitution for Europe, or the 2009 sovereign debt crisis - had to add another one: migrants stand ante portas and what to do with them? ${ }^{8}$

This recent, massive arrival of people to Europe caused a whole spectrum of reactions, from sympathy and enthusiasm to hostility, amongst all stakeholders and at all levels. Some commentators argued that because Europe has committed itself to the protection and promotion of high moral values and principles, and amongst them fundamental rights, it has to uphold them by welcoming and accommodating the irregular migrants. They see their arrival as a historical necessity, indispensable justice, economic opportunity and even as a new chapter in European history. Other commentators contrasted this viewpoint with an opinion that irregular migration is a multidimensional threat to the host polities. They have also called it an 'invasion' or a 'flood', linked to the rise of crime and terrorism; they have feared economic, social and cultural difficulties.

As a reaction, many people went to the streets. Some have marched with posters 'refugees welcome' in front of the many harbours and train stations where these people have been waiting to catch their connections whilst in transit on their journey. ${ }^{9}$ There were many people who offered a helping hand to refugees, starting with first aid. ${ }^{10}$ At the same time, there have been people protesting against the influx of migrants, carrying the slogan 'go home' and provoking racist and xenophobic reactions; the rates of hate crime have increased. Some

6 European Parliament, EU Migrant Crisis: Facts and Figures, Strasbourg, 30.06.2017, <http://www.europarl.europa.eu/news/en/headlines/society/20170629STO78630/eumigrant-crisis-facts-and-figures $>$.

7 The United Nations' High Commissioner for Refugees (UNHCR) maintains up-to-date statistics at <http://data2.unhcr.org/en/situations $>$. So does, inter alia, the IOM at $<$ http://migration.iom.int/europe $>$ and the European Border and Coast Guard Agency (Frontex) at $<$ http://frontex.europa.eu/trends-and-routes/migratory-routes-map >.

8 D. Dinan, 'Crises in EU History' in D. Dinan, N. Nugent and W.E. Paterson, The European Union in Crisis, Macmillan, London 2017, pp. 16-32.

9 E. Graham-Harrison, P. Kingsley, R. Waites and T. McVeigh, 'Cheering German crowds greet refugees after long trek from Budapest to Munich', The Guardian, 05.09.2015, <https:/www.theguardian.com/world/2015/sep/05/refugee-crisis-warm-welcome-forpeople-bussed-from-budapest $>$.

10 Their actions often met with appreciation. For instance, the Vrije Universiteit Brussel (VUB), where two of the editors of this book work, in November 2017 awarded doctorates honoris causa to Emma Bonino for her 'determined efforts in relation to migration and refugees' and to the 'inhabitants of Lampedusa', represented by Pietro Bartolo, for their 'charity and helpfulness'. Cf. 'Honorary doctorate for Dr. Emma Bonino and the inhabitants of Lampedusa', VUB Today, 28.11.2017, <http://www.vubtoday.be/en/content/honorary-doctorate-dr-emmabonino-and-inhabitants-lampedusa $>$. 
other people have voiced their opposition in even stronger ways, for example, by attacking refugee shelters. ${ }^{11}$

Political leaders in Europe have split accordingly. The contrast between the actions of Angela Merkel of Germany (e.g. introducing an 'open border' policy for refugees in 2015) ${ }^{12}$ and those of Viktor Orbán of Hungary (who built a barbed-wire fence throughout the Hungarian border with Serbia ${ }^{13}$ and claimed, most recently, cultural 'incompatibility' of migrants and the European societies) ${ }^{14}$ is illustrative of this discord. The EU and its Member States have responded with a combination of humanitarian- and security-oriented measures. For example, they reformed their legislative frameworks on external border control, ${ }^{15}$ asylum and immigration as well as launched search and rescue (S\&R) operations such as the Italian 'Mare Nostrum,' ${ }^{16}$ followed by the EU-coordinated border security operation 'Triton' ${ }^{17}$ and the EU military operation 'Sophia. ${ }^{18}$ In order to ease the burden on Italy and Greece, the EU have temporarily introduced

11 P. Oltermann, 'Crowd cheer fire at hotel being converted into refugee shelter in Saxony', The Guardian, 21.02.2016, <https:/www.theguardian.com/world/2016/feb/21/crowd-cheersfire-hotel-refugee-shelter-saxony-germany>; V. GARzA, 'Polish brothers plead not guilty for setting fire to asylum center', Norway Today, 10.10.2017, <http://norwaytoday.info/news/ polish-brothers-pleas-not-guilty-setting-fire-asylum-center $>$.

12 E. Graham-Harrison, P. Kingsley, K. Rawlinson and W. Murray, 'First Refugees Arrive from Hungary after Austria and Germany Open Borders', The Guardian, 05.09.2015, $<$ https://www.theguardian.com/world/2015/sep/05/refugees-travelling-from-hungary-canenter-germany-and-austria>.

13 A. SAndford, 'Hungary Completes New Anti-Migrant Border Fence with Serbia', Euronews, 28.04.2017, <http://www.euronews.com/2017/04/28/hungary-completes-new-anti-migrantborder-fence-with-serbia>.

14 E. Zalan, 'Orban Vows to Defend Poland from EU's Inquisition', EU Observer, 24.07.2017, $<$ https://euobserver.com/political/138586>.

15 Perhaps the most visible examples are: the reinforcement of the European Border and Coast Guard Agency (Frontex) and - what might have been noticed by many travellers the amendment of the Schengen Border Code, effective from 7 April 2017, that reinforced checks of all people at the external borders, both at entry and at exit. Cf. Regulation (EU) 2016/1624 of the European Parliament and of the Council of 14 September 2016 on the European Border and Coast Guard ..., [2016] OJ L251/1; Regulation (EU) 2017/458 of the European Parliament and of the Council of 15 March 2017 amending Regulation (EU) $2016 / 399$ as regards the reinforcement of checks against relevant databases at external borders, [2017] OJ L74/1. Cf. also S. Carrera S. Blockmans, D. Gros and E. Guild, 'The EU's Response to the Refugee Crisis. Taking Stock and Setting Policy Priorities', CEPS [Centre for European Policy Studies] Essay No. 20/16, Brussels 2015, <https://www.ceps.eu/ publications/eu's-response-refugee-crisis-taking-stock-and-setting-policy-priorities $>$.

16 Ministero della Difesa [Repubblica Italiana], Mare Nostrum, [no date], <http://www. marina.difesa.it/cosa-facciamo/operazioni-concluse/Pagine/mare-nostrum.aspx $>$.

17 European Commission, Frontex Joint Operation 'Triton' - Concerted efforts to manage migration in the Central Mediterranean, memo 14/566, Brussels, 07.10.2014, <http://europa. eu/rapid/press-release_MEMO-14-566_en.htm>.

18 European External Action Service, 'Mission EUNAVFOR MED - Operation SOPHiA', factsheet, Brussels, 20.10.2017, <http://eeas.europa.eu/sites/eeas/files/october_2017_-_ factsheet_on_eunavfor_med_mission_english.pdf $>$. 
emergency 'relocation and resettlement' schemes between Member States (also known as 'migrant quotas'), ${ }^{19}$ notwithstanding opposition from a few Member States, mainly due to the mandatory nature of these measures. ${ }^{20}$ The EU even 'agreed' with Turkey that all irregular migrants arriving from Turkey at a Greek shore would be returned. ${ }^{21}$ At the same time, courts of law - from national ones, at all levels, to supranational ones, that is, the European Court of Human Rights (ECtHR) and the Court of Justice of the European Union (CJEU) - have been more and more often seized by cases concerning immigration and the implications these measures produce for the values and principles on which Europe has been built.

Finally, the media, both digital and more traditional outlets, also took two diverging stances. Those unfavourable to irregular migration, especially in the 'new' EU Member States, rarely said anything positive about migrants. ${ }^{22}$ By contrast, those favourable attempted to counterbalance this negative coverage by, for example, depicting the many refugee ships and camps - such as in Calais, France - and paying special attention to death, illness and the living conditions therein. ${ }^{23}$ The photograph of the dead body of a three-year-old Syrian boy on a Turkish shore, named Alan Kurdi, is illustrative here. ${ }^{24}$ In parallel, artists ranging from literature to cinematography - took a rather favourable stance towards irregular migration and migrants. For example, Ai Weiwei's recent art installation on the streets of New York City display sculptures of fences and invites a 'reflection on the profound social and political impulse to divide people from each other'. ${ }^{25}$

19 Council Decision (EU) 2015/1523 of 14 September 2015 establishing provisional measures in the area of international protection for the benefit of Italy and of Greece [2015] OJ L239/146; Council Decision (EU) 2015/1601 of 22 September 2015 establishing provisional measures in the area of international protection for the benefit of Italy and Greece [2015] OJ L248/80. Cf. also European Commission, Twelfth Report on Relocation and Resettlement, COM(2017) 260 final, Strasbourg, 16 May 2017.

20 European Commission, Relocation: Commission launches infringement procedures against the Czech Republic, Hungary and Poland, press release, IP/17/1607, Brussels, 14.06.2017; CJEU, Case C-643/15 Slovak Republic and Hungary v. Council of the European Union, Judgment of 06.09.2017.

21 European Council, EU-Turkey Statement, Press Release 144/16, Brussels, 18.03.2016, $<$ http://www.consilium.europa.eu/en/press/press-releases/2016/03/18/eu-turkey-statement/pdf >.

22 J. Cieński, 'Why Poland Doesn't Want Refugees', Politico, 21.05.2017, <http://www.politico. eu/article/politics-nationalism-and-religion-explain-why-poland-doesnt-want-refugees $>$.

23 Human Rights Watch, Greece: Dire Refugee Conditions on Islands, Transfer Asylum Seekers to Mainland, 23.01.2017, <https:/www.hrw.org/news/2017/01/23/greece-dire-refugee-conditionsislands $>$.

24 H. Sмiтн, 'Shocking images of drowned Syrian boy show tragic plight of refugees', The Guardian, 02.09.2015, <https://www.theguardian.com/world/2015/sep/02/shocking-imageof-drowned-syrian-boy-shows-tragic-plight-of-refugees $>$.

25 A. Weiwei, Good Fences Make Good Neighbors, Public Art Fund, New York, NY, October 2017 - February 2018, <https://www.publicartfund.org/ai_weiwei_good_fences_ make_good_neighbors/about>. 
As with many aspects of public life, the reactions to irregular migration that we have sketched above are interrelated: media and politicians do influence the public opinion and vice versa. And we could continue recalling these stories from both ends of the spectrum, both positive and negative - as irregular migrants have not ceased to arrive in Europe; their journeys continue - but it is fair to conclude that migration remains a heated, multifaceted yet controversial topic. There exist two opposing viewpoints as to what to do in light of the fact that irregular migrants have already come to Europe, have been waiting ante portas or will arrive in the days to come - should Europe welcome them or send them back?

These two contrasting viewpoints stand behind the main idea for this book. We have chosen to look at the extent to which the past, the present and the future of irregular migration to Europe relates to the foundational values and principles on which Europe has been built, namely democracy, the rule of law (Rechtsstaat) and the respect for fundamental rights. We focus on those people who seek various forms of help in Europe, motivated by war or other injustices in the places where they come from. With this book we do not aim to offer any complete or ultimate answer - if this was ever possible - but rather we want to modestly partake in a debate on the appropriate way to deal with irregular migration.

\section{II.}

Let us set the scene before giving voice to the authors of the many chapters in this book. There are multiple ways of examining the past, the present and the future of irregular migration to Europe and the way it relates to the European foundational values and principles. We acknowledge these perspectives are neither exhaustive nor clear-cut, yet they have the advantage of clarifying the main drivers at stake.

1. Migration as an ethical question. The first amongst these perspectives, on our view, is to look from the moral philosophy (ethics) viewpoint, or - more concretely - theories of justice. We see the ethical reflection, in the context of irregular migration, as indispensable for minimum two reasons: first, we are concerned with human beings and thus the stakes are very high. Second, we have observed there has been too much noise in the debates on migration, yet there has not been enough wisdom therefrom; an ethical reflection is meant to remedy that. Ethics offers 'ideas about how to live'; it determines 'what we find acceptable or unacceptable, [...] it determines our conception of what is due to us, and what is due from us, as we relate to others. ${ }^{26}$ It has an ambition to be a supreme set of normative dispositions that defines the

26 S. Blackburn, Ethics. A Very Short Introduction, Oxford University Press, Oxford 2000, p. 1. 
'standards of behaviour'. ${ }^{27}$ Every day people make choices about their own lives and often about the lives of other people, for instance within a family or a group of friends or within a polity (e.g. governments). They frame their choices as a simple dichotomy between being 'good' or 'bad', between 'right' and 'wrong'; for many - a distinction between a sin or not. People probably do not necessarily realise their arguments and their decisions do have moral origins and ramifications, or - at least - that these arguments and decisions can be framed in ethical terms and analysed through the lens of formal 'tools' that ethics provides.

At the most rudimentary level, normative ethics offers a few approaches on how to decide what is the right thing to do. In Western philosophy, for example, if those favourable of migration claim that accepting refugees is all about human dignity, they believe in duty, for example to recognise this dignity and thus to help those in need; they are deontologists. They hold that all humans are worthy of respect, regardless of who they are or where they come from, and it is therefore wrong to treat them as mere instruments towards any given aim. ${ }^{28}$ (This is the legacy of Immanuel Kant, ${ }^{29}$ which often stands in opposition to e.g. Niccolò Machiavelli.) ${ }^{30}$ Libertarians, in their belief in human freedom, would rather welcome anybody, as these people are entitled to do whatever they want with their life and their property, provided they respect other people's rights to do the same. ${ }^{31}$ (This is the legacy of e.g. John Locke.) ${ }^{32}$ If those favourable to the accommodation of irregular migrants claim this would maximise overall good - that is, a greater happiness for the greatest number of people - then they look at consequences of actions. They take, in other words, a consequentialist stance, or - more precisely - a utilitarian stance: they have 'calculated' the pros to outweigh the cons. Yet the utilitarian calculus can equally demonstrate that disadvantages outweigh advantages. (This is the legacy of e.g. Jeremy Bentham ${ }^{33}$ and John Stuart Mill. $)^{34}$ Finally, those who follow virtue ethics (aretaic ethics), they would rather welcome and help a refugee since this would be a benevolent thing to do or because that would be what a virtuous person would do. (This is the legacy of Plato and Aristotle, revived by Elizabeth Ascombe in the twentieth century. $)^{35}$ We note that as virtues such as charity and altruism are rather straightforward, there are some - such as prudence (wisdom) - that can be variously interpreted in the context of migration.

\footnotetext{
27 Ibid.

28 M.J. Sandel, Justice. What's the Right Thing to Do?, Penguin, London 2009, p. 103.

29 Cf. e.g. I. KANT, Grundlegung zur Metaphysik der Sitten [Groundwork of the Metaphysic of Morals], 1785.

30 Cf. e.g. N. Machiavelli, Il Principe [The Prince], 1532.

31 M.J. SANDEL, supra n. 28, pp. 59-60.

32 Cf. e.g. J. Locke, Two Treatises of Government, 1689.

33 Cf. e.g. J. Bentham, An Introduction to the Principles of Morals and Legislation, 1789.

34 Cf. e.g. J.S. MiLl, On Liberty, 1859.

35 G.E.M. Anscombe, 'Modern Moral Philosophy', (1958) 33(124) Philosophy 1.
} 
These schools of normative ethics take a different unit of measure (e.g. communitarian or individual well-being), they are often mutually exclusive and they rarely provide any ultimate answer. The reason why we just mentioned them is that they stand behind any legal statue, any political decision or any deed made in public and private lives, even though the importance of ethics might not initially be so visible.

At a more concrete level, applied ethics has already devoted considerable attention to the phenomenon of migration and to the migrant as a person, regardless of whether regular or not. From the richness of such discourse, we can immediately recall at least Emmanuel Levinas and his emphasis on the encounter with another human being, 'the Other'. Levinas claims not only that the meeting with the Other is the most important experience in human life, but also that ' $\mathrm{I}$ ' has to take some responsibility and to care for 'the Other. ${ }^{36}$ A migrant is another human being and his or her arrival to a new polity would constitute such a profound experience, a meeting, and would demand the host to take some responsibility. It is fascinating that someone else is different; such an encounter often brings a totally different understanding of the world, thus enrichment. ${ }^{37}$

2. Migration as a legal question. The second perspective is that of law, including its ethical foundations as well as the legal practice. It is the law that has predominantly been used to regulate migration and the status, rights and duties of a migrant. $^{38}$

Generally speaking, political systems in the majority of democratic polities have been built on some main values and principles, 'ideals that dominate [...] political morality', in particular democracy, the rule of law (Rechtsstaat), the respect for fundamental rights and economic freedom. ${ }^{39}$ This is so because these ideals appeal to many as an appropriate way of public organisation and - as

36 E. Levinas, Totalité et Infini. Essai sur l'extériorité [Totality and Infinity: An Essay on Exteriority], Martinus Nijhoff, La Haye 1961. Cf. also R. KAPUściński, Ten Inny [This Other], Znak, Kraków 2006.

37 We recall here a media campaign run by Amnesty International in mid-2016, titled 'Look Beyond Borders', in which an experimental video film depicting a short encounter between a European and a recently-arrived refugee was shown to 'break down barriers'. The idea was based on a 'theory that four minutes of uninterrupted eye contact increases intimacy'. Cf. Amnesty International, 'Look refugees in the eye: Powerful video experiment breaks down barriers', press release, 24.05.2016, <https:/www.amnesty.org/en/latest/news/2016/05/ look-refugees-in-the-eye $>$.

38 There exist many mechanisms of regulation. For their classical overview, cf. e.g. C.C. Hood, The Tools of Government, Macmillan, London 1983, pp. 2-11.

39 J. WALdron, 'The Rule of Law and the Importance of Procedure' in J. Fleming (ed.), Getting to the Rule of Law, New York University Press, New York 2011, p. 3, <http://lsr.nellco.org/ cgi/viewcontent.cgi? article=1235\&context=nyu_plltwp $>$. Yet we acknowledge these 'ideals' have been, over the time, variously conceptualised. For the sake of clarity, it suffices here to explain that both the rule of law and Rechtsstaat doctrines serve multiple purposes in a 
Dahl put it - amongst these ideals, democracy 'uniquely possesses a number of features that most people, whatever their basic political beliefs, would consider desirable' ${ }^{40}$ The laws of these polities, and in particular their highest legal norms their magnae cartae, aim at the protection of these ideals (at minimum) and their promotion (at best). As Agnes Callamard, the UN Special Rapporteur on extrajudicial, summary or arbitrary executions - whilst reporting on migration has observed:

[t]he right not to be arbitrarily deprived of life is a foundational and universally recognized right, applicable at all times and in all circumstances, including during armed conflict or other public emergency. The right to life - a norm of jus cogens is protected by international and regional treaties, customary international law and domestic legal systems. ${ }^{41}$

The legal provisions that are of our particular interest are those affecting the polity of Europe. ${ }^{42}$ Generally speaking, human rights have become, at a certain

polity and one of them is to channel the exercise of 'public power through law'. They achieve their goals in different manners and hence function differently while sharing some common characteristics. The rule of law doctrine dominates on the British Isles, the Rechtsstaat - on the continental Europe. Cf. e.g. G. Lautenbach, The Concept of the Rule of Law and the European Court of Human Rights, Oxford University Press, Oxford 2013, p. 18.

40 R. A. DAhL, 'The value of democracy' Encyclopodia Britannica, 2017, <https://www.britannica. com/topic/democracy/The-value-of-democracy>.

41 United Nations, Report of the Special Rapporteur of the Human Rights Council on extrajudicial, summary or arbitrary executions, New York, 15.08.2017, A/72/335, \$14.

42 The reader deserves a word of explanation. We understand Europe sensu largo - it is a patchwork of supranational arrangements of economic and political nature occurring on the European continent, of individual countries that partake in these arrangements as well as of their inhabitants, regardless if citizens or not. In geographical terms, this polity comprises the EU with the non-EU members of the European Economic Area (EEA), Switzerland as well as four microstates - Monaco, Andorra, San Marino and the Vatican City/Holy See - that partake with a varying degree in these policies. All of them but the Vatican City/Holy See are members of the Council of Europe (CoE). The Council of Europe, in turn, tasked with safeguarding and promoting democracy, the rule of law (Rechtsstaat), fundamental rights and social development, currently comprises 47 Member States, i.e. virtually all countries on the European soil, with a notable exception of Belarus. (Cf. the Statute of the Council of Europe, London, 05.05.1949; European Treaty Series (ETS) No. 1, as amended.) Eventually, the EU is a much more closely integrated economic and political union of 28 Member States. Its main economic component - the internal market - has been open to four other countries, i.e. Norway, Iceland and Liechtenstein (linked thereto via the EEA Agreement) - as well as Switzerland (linked via bilateral agreements). In parallel, a part of EU political output e.g. common migration and asylum policy - affects, to a various degree, also these four counties and four microstates too and this is why our object of interest - geographically speaking - comprises 36 countries. In parallel, at the regional level, there exists also a few politico-economic unions, such as Benelux (Belgium, the Netherlands and Luxembourg) and a few loose, political alliances, such as the Visegrád Group (Poland, Hungary, the Czech Republic and Slovakia) or the Weimar Triangle (France, Germany and Poland). Let us borrow a commonly used phrase 'European integration project' to refer, for our purposes, to this patchwork of arrangements. 
point, a narrative of the European integration project. ${ }^{43}$ They can be analysed at three levels. Their first manifestation is the work of the Council of Europe. When we look at its legal system, the European Convention on Human Rights (ECHR, 1950) ${ }^{44}$ affords the protection of fundamental rights of any person, i.e. regardless of their citizenship or lack thereof, who happens to find him- or herself under the jurisdiction (sensu largo) of any the Council's Member States. Therefore, irregular migrants benefit too. The Convention established the European Court of Human Rights (ECtHR), sitting in Strasbourg, and the bulk of the legal rules on migration originates from its judgments. Empirically speaking, in the context of migration, the Court has been seized thus far to adjudicate on cases concerning the prohibition of torture (Article 3 ECHR), right to liberty and security (Article 5), right to privacy (Article 8) and the right to effective remedy (Article 13) ${ }^{45}$ In parallel, the European Social Charter $\left(1961,{ }^{46}\right.$ revised 1996) ${ }^{47}$ is often seen as a complementing instrument to the ECHR, yet it lacks any strong enforcement mechanisms - the European Committee of Social Rights monitors the implementation of the Charter yet it has no binding powers whatsoever. ${ }^{48}$ Concerning specifically irregular migration, the Council of Europe appointed in February 2016 its first Special Representative on Migration and Refugees and tasked him, inter alia, to monitor and 'gather information on how the fundamental rights of migrants and refugees are protected'; ${ }^{49}$ this is meant to aid policy-making.

The second manifestation of human rights as a narrative of the European integration project is the European Union (EU). Initially conceived as an economic endeavour to secure peace and prosperity, ${ }^{50}$ what is now the EU has been gradually exercising more and more public authority in a growing number of fields and hence, at a certain point, the question of democratic legitimacy came to the fore. Following the decades of political and academic debates - and resulting constitutional changes - the foundational Treaties have progressively been reflecting the democratic nature (sensu largo) of the

43 S. Smismans, 'Fundamental rights as a political myth of the EU: can the myth survive?' in S. Douglas-Scott and N. Hatzis (eds.), Research Handbook on EU Law and Human Rights, Edward Elgar Publishing, London 2017, pp. 13-34; G. DE BúrCA, 'The Language of Rights and European Integration' in J. SHAw and G. More (eds.), New Legal Dynamics of the European Union, Oxford University Press, Oxford 1995, pp. 24-34.

44 Convention for the Protection of Human Rights and Fundamental Freedoms, Rome, 04.11.1950; ETS No. 5, as amended; most recently by Protocol No. 16, Strasbourg, 02.10.2013; ETS No. 214.

45 ECtHR, Press Unit, Migrants in Detention, factsheet, July 2017, <http://www.echr.coe.int/ Documents/FS_Migrants_detention_ENG.pdf>.

$46 \quad$ ETS No. 35.

47 ETS No. 163.

48 Cf. $<$ http://www.coe.int/t/democracy/migration/bodies/ecsr_en.asp $>$.

49 Cf. <https://www.coe.int/en/web/special-representative-secretary-general-migration-refugees/ home $>$.

50 Cf. supra n. 42. 
European integration project. In the most recent wording, amongst the values and principles on which the Union has been built, the 'respect for human dignity' stands primus inter pares. We read this from Article 2 of the Treaty on the European Union (TEU), as lately amended by the Treaty of Lisbon (2009):

The Union is founded on the values of respect for human dignity, freedom, democracy, equality, the rule of law and respect for human rights, including the rights of persons belonging to minorities. These values are common to the Member States in a society in which pluralism, non-discrimination, tolerance, justice, solidarity and equality between women and men prevail. ${ }^{51}$

We supplement this observation with a set of rules for the democratic functioning of the Union, such as the equality of citizens and the representative democracy (Articles 9-12 TEU), ${ }^{52}$ and the entry into force of the legally binding Charter of Fundamental Rights of the European Union (CFR, 2009). The importance of the Charter is unparalleled: in order to ensure the practical, effective and efficient protection of human rights, the EU has bound itself by a 'bill of rights' that serves as a benchmark against which the secondary EU law and the law of the Member States implementing EU law is checked. Article 1 confirms the commitment to these values and principles as the Charter opens with the statement that ' $[\mathrm{h}]$ uman dignity is inviolable. It must be respected and protected'. 53

Third and finally, all European countries partake in the global system for the protection of fundamental rights. All are members of the United Nations (UN), the majority supported the adoption of the Universal Declaration of Human Rights (UDHR, 1948) ${ }^{54}$ and all signed the legally binding International Covenant on Civil and Political Rights (ICCPR, 1976) as well as the many subsequent human rights treaties. The protection of fundamental rights is further enshrined in their national constitutions.

More concretely, when it comes to the regulation of irregular migration - this including the safeguarding of migrants' rights - we observe it occurs at four levels:

1. International - the UN, whose Convention Relating to the Status of Refugees, signed in Geneva in 1951 (i.e. 'the 1951 Refugee Convention'), ${ }^{55}$ and a subsequent Protocol, signed in New York in 1967, constitute the key legal

[2016] OJ C202/389. Yet note Protocol No. 30 and declarations Nos. 53 and 61-62 by the UK, Czech Republic and Poland on the Charter of Fundamental Rights of the European Union, [2016] OJ C202/312 and 358.

52 A. von Bogdandy, 'The European lesson for international democracy: The significance of Articles 9 to 12 EU Treaty for international organizations' (2012) 23 European Journal of International Law 315.

53 Supra n. 51.

54 UN, General Assembly, Resolution 217 A, Paris, 10.12.1948.

55 United Nations Treaty Series (UNTS) Vol. 189 (1954), No. 2545. 
framework in our field of interest, defining the status of a refugee, vesting in him or her some basic rights and requiring a state to take some action benefiting refugees. ${ }^{56}$ The importance of both the Convention and its Protocol lies in the fact that these instruments constitute a worldwide reference framework for irregular migration, having been ratified by altogether 148 parties, and that the principle of non-refoulement they contain (i.e. a right of an asylum seeker not to be sent back to a country in which he or she would be in likely danger of persecution; Article 33) is nowadays widely considered a jus cogens norm (i.e. a pre-emptory norm with no derogation) in international law. ${ }^{57}$ To manage irregular migration around the world, the UN created the office of the High Commissioner for Refugees (UNHCR) in 1950.

2. Supranational, or regional - in particular those arrangements in Europe, the Americas and Africa; each of these have undertaken legal steps to regulate irregular migration and migrants, within their competences and within their respective jurisdictions; while we overview the European legal framework infra, some notable examples from elsewhere could include the Organisation of African Unity's Refugee Convention (1969) ${ }^{58}$ or the Cartagena Declaration on Refugees, concerning Latin America (1984). ${ }^{59}$

3. National - an individual country in which its national constitution, primary and secondary legalisation regulate migration and migrants. Concerning the right to asylum, for example, most countries provide this through domestic legislation, in particular by a statute incorporating the 1951 Refugee Convention. However, France, Italy, Germany and Poland stand out as four of very few European countries specifically to guarantee such a right in their national constitutions. ${ }^{60}$

56 Article 1(A)(2) defines refugee as a person, who 'owing to well-founded fear of persecution for reasons of race, religion, nationality, membership of a particular social group or political opinions, is outside the country of his nationality and is unable or, owing to such fear, is unwilling to avail himself of the protection of that country'. In other words, a refugee is a person not protected by his or her own state - however this link is understood - and thus the international community steps in to offer such a protection. Article $1(\mathrm{~F})$ excludes from this group people 'to whom there are serious reasons for considering that: (a) he has committed a crime against peace, a war crime, or a crime against humanity, ... (b) he has committed a serious non-political crime outside the country of refuge prior to his admission to that country as a refugee; (c) he has been guilty of acts contrary to the purposes and principles of the United Nations'.

J. Allain, 'The Jus Cogens Nature of Non-Refoulement' (2001) 13(4) International Journal of Refugee Law 533.

58 Convention governing the Specific Aspects of Refugee Problems in Africa, Addis Adaba, 10.09.1969; UNTS Vol. 1001 (1976), No. 14691.

59 Cartagena Declaration on Refugees, 22.11.1984, <http://www.refworld.org/docid/3ae6b36ec.html>.

60 H. Lambert, F. Messineo and P. Tiedemann, 'Comparative Perspectives of Constitutional Asylum in France, Italy, and Germany: Requiescat in Pace?' (2008) 27(3) Refugee Survey Quarterly 16. Cf. also Article 53-1 of the French Constitution (JORF [1958] 238/9151, as amended), Article 10 of the Italian Constitution (GU [1947] 298/1, as amended), Article 16a of the German Constitution (BGBl [1949] III/100-1, as amended) and Article 56 of Polish Constitution ([1997] OJ 78/483, as amended). 
4. Cross-institutional - multiple stakeholders at multiple levels may become involved in the regulation of irregular migration and migrants; the most recent example is a code of conduct proposed by the Italian government for the many non-governmental organisations (NGOs) who, on their vessels, have attempted to save refugees on the Mediterranean. ${ }^{61}$

When we look at the EU and the regulation of migration, at a pragmatic level, the first key concept that comes to our minds is the so-called Schengen Area, which has abolished physical border controls among the vast majority of European countries and became one of the core pillars of the European integration project. The second is the Dublin system, introduced in the early 1990s, which is a set of rules overseeing the admission of asylum seekers; it states the principle that the country of the first entry of the asylum seeker is to examine his or her application and that the asylum seeker is prohibited from (re-)applying in other Member States. ${ }^{62}$ These two are interlinked: the abolition of internal border controls requires the strengthening the control of external borders, which - in turn - necessitates a common policy on migration.

But this does not exhaust the whole picture. At a constitutional level, Article 18 CFR grants a right to asylum in accordance with the 1951 Refugee Convention and Article 19 prohibits the return of migrants should they face danger (i.e. non-refoulement). The Treaty on the Functioning of the European Union (TFEU) ${ }^{63}$ calls on the EU to develop a 'common policy on asylum, immigration and external border control' (Article 67) as well as a common policy on 'asylum, subsidiary protection and temporary protection with a view to offering appropriate status to any third-country national requiring international protection and ensuring compliance with the principle of non-refoulement' (Article 78). Both the EU and its Member States have a say in the shape of these policies; in other words, irregular migration and asylum constitute a shared competence, as contrasted to, for example, the customs union, which constitutes an exclusive responsibility of the EU (Article 4 TFEU). ${ }^{64}$

61 C. Balmer, 'Italy Drafts Contested Code of Conduct for NGO Migrant Boats', Reuters, 13.07.2017, <https://af.reuters.com/article/topNews/idAFKBN19Y0MH-OZATP >. We refrain here from commenting on the contents of the said Code of Conduct.

62 Currently in its third iteration, cf. Regulation (EU) No 604/2013 of the European Parliament and of the Council of 26 June 2013 establishing the criteria and mechanisms for determining the Member State responsible for examining an application for international protection lodged in one of the Member States by a third-country national or a stateless person, [2013] OJ L180/31. However, Protocol 24 to the TEU and TFEU, generally speaking, rules out a possibility for a citizen of an EU Member State to seek asylum in another Member State; Belgium is a notable exception to that rule. Cf. S. Top, 'The European Arrest Warrant against Puigdemont: A Feeling of Déjà Vu?', EJIL: Talk!, 03.11.2017, <https://www.ejiltalk.org/theeuropean-arrest-warrant-against-puigdemont-a-feeling-of-deja-vu $>$.

63 Supra n. 51.

64 To conclude this part, the law on migration has been subject to prolific academic and professional commentary. Cf. e.g. European Union Agency for Fundamental Rights 
Here we hasten to note that the focus of this book is not devoted to migration within a single country (i.e. internal migration). Neither is this book concerned with a key aspect of the European integration project - wherein intra-European migration has seen unprecedented freedom of movement of persons ${ }^{65}$ - or regular migration, but rather this book is devoted to the arrival at the external borders of Europe of the 'outsiders', that is, third country nationals and, to some extent, stateless people, who are seeking either international protection as asylum seekers (i.e. humanitarian migration) or seeking a better way of life as economic refugees. In other words, this book is largely preoccupied with, as the IOM puts it, 'irregular migration' to Europe.

(FRA), Handbook on European law relating to asylum, borders and immigration, 2nd ed., Luxembourg 2015, <http://fra.europa.eu/en/publication/2013/handbook-european-law-relatingasylum-borders-and-immigration>; M. KahaneC and K.F. Zimmermann (eds.), Labor Migration, EU Enlargement, and the Great Recession, Springer, Berlin-Heidelberg 2016; S. Castles, H. De HaAs and M.J. Miller (eds.), The Age of Migration: International Population Movements in the Modern World, Palgrave Macmillan, London 2013; M.N. Rosenblum and D.J. Tichenor (eds.), The Oxford Handbook of the Politics of International Migration, Oxford University Press, Oxford 2012; S. Peers, E. Guild, J, Tomkin, V. Moreno Lax and M. Garlick, EU Immigration and Asylum Law (Text and Commentary): Second Revised Edition, Martinus Nijhoff, Leiden 2012; R. Rubio-Marín, Human Rights and Immigration, Oxford University Press, Oxford 2014; F. Cherubini, Asylum Law in the European Union: From the Geneva Convention to the Law of the EU, Routledge, New York 2015; V. Mitsilegas, The Criminalisation of Migration in Europe. Challenges for Human Rights and the Rule of Law, Springer, Dordrecht 2015.

65 Again, the reader deserves a word of explanation. The EU, in its economic aspect, is built on a few bases and one of them is 'four freedoms' that ensure free movement of goods, capital, services and persons (labour) between the EU Member States. (Another base, a political one, is e.g. the already mentioned respect of human dignity, realised mainly by the protection of fundamental rights.) These four freedoms grew gradually, by a combination of some visionary thinking and trial-and-errors, since the European integration project commenced in 1950s. In the context of intra-European migration - in essence and with the risk of over-simplification - any citizen of the Union (a status conferred thereupon since 1993 by a mere fact of possessing a citizenship of one of the Member States) can freely travel, reside, study, work, retire and own immovable property in any Member State of the Union. (There are exceptions, of course.) These freedoms are extended to EEA States as well as to Switzerland, although, again, not without exceptions. These freedoms - or, to a large extent, the abolition of relevant restrictions - are further strengthened by the elimination of physical controls at national borders between the majority of countries on the European soil. The so-called Schengen Area (named for the place where the relevant agreement was signed in 1985) comprises, at the time of writing, 22 EU Member States, three EEA Member States and Switzerland. Some European 'micro-states' which have an open border with a neighbouring EU Member State, e.g. Monaco, are de facto included too. (But not Andorra.) By contrast, excluded are e.g. some parts of some Member States that are outside geographical Europe, e.g. Réunion (a French région d'outre-mer), or have a special status within Europe, e.g. Svalbard in Norway or Mount Athos in Greece. However, physical checks at some internal borders can be exceptionally, and for a short period of time, re-installed as a response to some threat or emergency. The recent migration 'crisis' to which the present book has been devoted, is one of such emergencies. Cf. further a classic: P. Craig and G. DE BúrCA, EU Law: Text, Cases, and Materials, 5th ed., Oxford University Press, Oxford 2011. 
3. Migration as an uncertain question. The third perspective, on our view, looks at the future consequences of migration. In addition to the obvious advantages and disadvantages for migrants themselves, migration as a phenomenon regardless of being regular or not - might bring multiple benefits to a hosting polity, but it might equally bring detriment thereto by, for instance, threatening their security and well-being. Correspondingly, migrants themselves might fall victim of hostility of a hosting polity, where - once legally admitted - they might feel less welcome, find it difficult to integrate and even fall victim of humiliation and hate crime. And while they await the result of their asylum application, they might suffer from the fear of rejection (and thus deportation) or - as doctors in Sweden put it - 'Uppgivenhetssyndrom' (resignation syndrome). ${ }^{66}$

Commentators usually explain the positive impact of migration in economic terms, in particular in the areas of the labour market, public purse and economic growth. Migrants fill important niches both in fast-growing and declining sectors of the economy by bringing new skills and abilities to their hosts and often contributing more to the state budget (e.g. in taxes) than they actually take therefrom (e.g. in benefits). ${ }^{67}$ Migration, in parallel, profoundly - and, on some occasions, creatively - impacts the culture and heritage of the hosting polity, in areas ranging from less obvious ones, such as cuisine and food consumption, sport or fashion, to more visible ones, such as language and art. The landscape is often more diverse as a result as the migrants are present in all cultural sectors.

Some commentators contrast these positive, economic and cultural impacts of migration against the negative impacts, such as dangers to national security, political system, social structure and demography as well as economy and cultural heritage, among others. They see it as a 'Trojan horse' and argue it is difficult, if not impossible, to differentiate between those migrants who come as friends and those who come as foes. Thus, they claim, migrants increase the threat of petty crimes as well as of serious ones, including terrorism. More broadly, they see them as a threat to stability, safety and public security. They argue migrants threaten traditions, values and identity of hosting polities. These commentators most often claim that migrants 'steal jobs' as they tend to work for a lower wage than the hosts. They even point out that the different ethnical and cultural background of migrants makes it difficult, if not impossible, for them to integrate and - if this is desired - assimilate. ${ }^{68}$ The experience of

66 R. Aviv, 'The Trauma of Facing Deportation', The New Yorker, 03.04.2017, <https://www. newyorker.com/magazine/2017/04/03/the-trauma-of-facing-deportation $>$.

67 Organization for Economic Cooperation and Development (OECD), Migration Policy Debates: Is Migration Good for the Economy?, Paris, May 2014, <https://www.oecd.org/ migration/OECD\%20Migration\%20Policy\%20Debates\%20Numero\%202.pdf>.

68 M. Haisler and Z. Layton-Henry, 'Migration and the Links between Social and Societal Security' in O. Wæver, B. Buzan, M. Kelstrup and P. Lemaitre (eds.), Identity, Migration and the New Security Agenda in Europe, Pinter, London 1993, pp. 148-166. 
immigrants many times confirms such difficulties as their 'social acceptance' is often 'conditional upon [their] very best behaviour'.69

The stark contrast between the two positions outlined above can be also understood by differentiating between 'wanted' or 'unwanted' migration. Migrants are usually wanted when the hosting polity, due to labour shortages, either lacks high-skilled migrants or needs low-skilled migrants. ${ }^{70}$ To that end, such a polity usually opens regular, legal channels for immigration. For instance, the 'green card lottery' in the United States is perhaps the most known example. In the EU, the so-called 'Blue Card' gives the right for highly qualified third-country nationals to reside and work in the territory of a EU Member State. ${ }^{71}$ When it comes to 'unwanted' migration, the hosting polity would 'rather be without' it, yet it often de facto has to live with it. Such migrants are usually those whose return is impossible even if their claims for protection are rejected (i.e. 'unavoidable' migrants) and those who were granted asylum or who are admitted for family reunification (i.e. 'reluctantly accepted'). ${ }^{72}$

This bring us to our third perspective on understanding migration, that is, one of profound uncertainty of the consequences of migration. Here we ask about the future, yet we do not possess enough knowledge to make any fully informed decision how to act. We not only do not know how a given issue of societal importance could develop (i.e. 'unknown knowns'), but - more importantly - we do not even know what other societal issues could possibly be affected or raised (i.e. 'unknown unknowns'). Regardless of the view that prevails (i.e. migration is good or bad) and, even if we take a consequentialist stance, regardless of whether the negative impacts that can be overcome and positive impacts maximised, the many effects that migration brings to the fore are impossible to be predicted in full, if ever. (This is true for many aspects of life.) This, in turn, scares people and often fuels opposition towards migration, both regular and irregular.

4. Migration as an omnipresent question. The fourth and final perspective, on our view, is that of history. Many commentators view the status quo of irregular migration to Europe as 'the defining issue of our times. ${ }^{73} \mathrm{~A}$ few others add that it has been an 'unprecedented' phenomenon, in a sense of the

69 M. Oкwonga, 'The Ungrateful Country' in N. Shukla (ed.), The Good Immigrant, Unbound, London 2017, p. 231.

70 J. CARling, 'The European Paradox of Unwanted Migration' in J.P. Burgess and S. Gutwirth (eds.), A Threat Against Europe? Security, Migration and Integration, VUB Press, Brussels 2011, pp. 33-34.

71 Council Directive 2009/50/EC of 25 May 2009 on the conditions of entry and residence of third-country nationals for the purposes of highly qualified employment [2009] OJ L155/17. The 'Blue Card' system does not apply to Denmark, Ireland and the United Kingdom.

72 J. CARLING, supra n. 70, pp. 34-35.

73 K.B. Harpviken, Foreword, in this volume, p. v. 
scale, difficulty and the lack of any predecessor. ${ }^{74}$ Conversely, other analysts claim the 'crisis rhetoric' has been only a media 'hype', fuelled by the quest to sensationalise the problem in order to grab public attention, and, in this way, constituting a useful political tool, ${ }^{75}$ yet hard numbers do not necessarily support that view. ${ }^{76}$ We agree that irregular migration nowadays is a 'defining' concern, yet we disagree it is anyhow 'unprecedented'. Migration has always been a part of Europe as it was a part of any other continent on this planet. From the beginning of history, the inhabitants of place X or Y either were moving to other places or other people were coming to place X or Y, in large or small numbers. Some of them have had very serious reasons, often ambiguous and concurring - to look for some form of help, to flee some injustice or to seek better living conditions - and strong motivation, only fuelled by despair since - as Bob Dylan has sung - 'when you ain't got nothing, you got nothing to lose. ${ }^{77}$ The UN adopted The New York Declaration for Refugees and Migrants in September 2016, admitting that:

[s]ince earliest times, humanity has been on the move. Some people move in search of new economic opportunities and horizons. Others move to escape armed conflict, poverty, food insecurity, persecution, terrorism, or human rights violations and abuses. Still others do so in response to the adverse effects of climate change, natural disasters (some of which may be linked to climate change), or other environmental factors. Many move, indeed, for a combination of these reasons. ${ }^{78}$

Yet we acknowledge some other people have less pressing reasons, such as a wish for bettering their lives (predominantly in economic terms) or, simply, to satisfy their curiosity about the world. People have been, do and will be moving from one part of the world to another, for a shorter or longer period of time, or even permanently. Sometimes they would be expected and welcome, some other times - not or not so much. In other words, '[t]he story of humanity is essentially the story of human movement ${ }^{79}$ and, from this viewpoint, it will just continue to be so.

74 D. Dinan, N. Nugent and W.E. Paterson, 'Conclusions: Crisis Without End?' in D. Dinan, N. Nugent and W.E. Paterson, The European Union in Crisis, Macmillan, London 2017, pp. $360-75$.

75 J. Ramji-Nogales, 'Migration Emergencies' (2017) 68(3) Hastings Law Journal 616.

76 G.J. Abel and N. SANDER, 'Quantifying Global International Migration Flows' (2014) 343 Science 1520; G.J. Abel, Estimates of Global Bilateral Migration Flows by Gender Between 1960 and 2010, working paper No. 2/2016, Vienna Institute of Demography, Vienna, pp. 1-32, <https://www.oeaw.ac.at/fileadmin/subsites/Institute/VID/PDF/Publications/Working_ Papers/WP2016_02.pdf>.

77 B. Dylan, Like a Rolling Stone, 1965.

78 United Nations, General Assembly, The New York Declaration for Refugees and Migrants, New York, 19.09.2016, A/RES/71/1.

79 P. Kingsley, The New Odyssey: The Story of Europe's Refugee Crisis, Guardian Faber Publishing, London 2016, p. 264. 
Each country has had its own immigration and emigration trends and traditions. There are countries 'built' on migration, for instance the United States of America or Canada, and there are countries that have seen almost no immigrants, but only emigrants. (A list thereof would be quite long here.) To take the United Kingdom (UK) as an illustrative example, the British - following the end of the Second World War and the related shortage of labour - encouraged immigration from predominantly former colonies, gathered under the Commonwealth of Nations. It was clear that colonial links and networks (i.e. political, economic and cultural) constituted major determinants of the origins and composition of immigrants. ${ }^{80}$ In addition, the UK recruited the so-called European Volunteer Workers, predominantly from Eastern European countries under Soviet influence. However, this initially favourable approach to immigration manifested by, for example, the British Nationality Act 1948 affirming the right of Commonwealth citizens to settle in the $\mathrm{UK}^{81}$ - changed a few decades later. For example, in 1972 the Leicester City Council placed an advertisement in an Ugandan newspaper to discourage the arrival of Ugandan Asians expelled by the regime of Idi Amin. ${ }^{82}$ The British Nationality Act 1981 placed restrictions on the originally automatic right to citizenship. ${ }^{83}$ The enlargement of the EU in 2004 invited a new wave of immigration from the East of Europe, as the UK was one of the few 'old' Member States that immediately granted free movement to these workers. The current political climate surrounding the so-called 'Brexit' process (i.e. the withdrawal of the UK from the EU) has placed migration at the fore of discussion, with little known about the future of other EU citizens living in the UK and significant resistance to the implementation of agreements to assist with the safe resettlement of asylum seekers. ${ }^{84}$

To take Poland as a further example, at several points in the nineteenth century - after the loss of independence from 1795 until 1918 - Poles have fled their country, for example seeking refuge from repressions after many failed uprisings against occupying powers. At the same time, many Poles were forcibly deported to Siberia. Then, they were escaping the atrocities of Second World War and - motivated, in addition, politically - in the aftermath thereof,

M. Czaika and H. De HaAs, Determinants of Migration to the UK, briefing, Migration Observatory, University of Oxford, 11.10.2017, <http://www.migrationobservatory.ox.ac.uk/ wp-content/uploads/2016/04/Briefing-Determinants-of-Migration-17-1.pdf >.

$81 \quad 11 \& 12$ Geo. 6 c. 56

82 BBC, Ugandan Asians advert 'foolish', says Leicester councillor, 08.08.2012, <http://www.bbc. com/news/uk-england-leicestershire-19165216>.

831981 c. 61.

84 A. Gentleman, 'Legal Challenge to Cap on Dubs Child Refugee Scheme Fails', The Guardian, 02.11.2017, <https://www.theguardian.com/world/2017/nov/02/child-refugee-legal-challengedubs-government-scheme-fails $>$. 
when the East of Europe was put into the sphere of the Soviet influence, ${ }^{85}$ as well as after the introduction of martial law in 1981, as a consequence of the Solidarność movement. Notably, after the so-called 'March 1968' thousands of Polish Jews were forced to leave the country with a one-way passport. It was predominantly the United States, Canada, the UK and France that welcomed them. ${ }^{86}$ After the restitution of democracy in 1989, migration to seek better living opportunities has also been present, which has intensified gradually since 2004 when Poland joined the EU, enabling Poles to freely live and work in other Member States of the EU/EEA and in Switzerland. In recent years, the trend has been changing: Poland has not only faced emigration to the West of Europe, but also it is slowly becoming a destination for many Eastern Europeans for a mixture of economic and political reasons: nowadays, Ukrainians constitute the biggest nationality migrating to Poland. ${ }^{87}$

Despite our emphasis on a single type of migration (i.e. irregular) in one particular geographical area (i.e. Europe) and in one particular direction (i.e. to Europe), we acknowledge that irregular migration is not solely a European phenomenon. ${ }^{88}$ We recognise the status quo of irregular immigrants in other parts of the world is, at this moment in time, often much more in dire need of political and, arguably, academic attention. ${ }^{89}$ Outside Europe, migration has recently made headlines with, for example, the United States President's executive orders to restrict immigration, ${ }^{90}$ ongoing forced displacement in Colombia ${ }^{91}$ and South Sudan, ${ }^{92}$ the Rohingya refugee crisis in

85 For the account of the Polish intelligentsia fleeing the communist rule, cf. especially the memoirs of Henryk Grynberg, who claimed that in late 1940s ‘... anyone who could, slipped away ... the new clique did not care, quite the contrary: the more gone, the better' (translation ours). H. Grynberg, Uchodźcy [Refugees], Świat Książki, Warszawa 2004, p. 8.

D. Stola, Kraj bez wyjścia? Migracje z Polski 1949-1989 [A Country with No Escape? Migrations from Poland 1949-1989], Instytut Pamięci Narodowej, Warszawa 2010; P. MilzA (ed.) L'émigration politique en Europe aux XIX et XX $X^{e}$ siècles, École Française de Rome, Rome 1991. I. Jóźwiak and M. Piechowska, Crisis-driven Mobility between Ukraine and Poland. What Does the Available Data (Not) Tell Us, working paper Nr 99(157), Centre of Migration Research, University of Warsaw, 2017, <http://www.migracje.uw.edu.pl/wp-content/uploads/ 2017/05/WP99157.pdf>.

88 F. Trauner, 'Asylum Policy: The EU's "Crises" and the Looming Policy Regime Failure' (2016) 38(3) Journal of European Integration 319.

89 Cf. e.g. the Uppsala Conflict Data Program at <http://ucdp.uu.se>.

90 D. BARrett, 'White House expands travel ban, restricting visitors from eight countries', The Washington Post, 24.09.2017, <https://www.washingtonpost.com/world/national-security/ trump-administration-changes-travel-ban-countries/2017/09/24/1fef7cfe-a140-11e7-ade176d061d56efa_story.html>.

91 UNHCR, 'Forced displacement growing in Colombia despite peace agreement', briefing, 10.03.2017, <http://www.unhcr.org/news/briefing/2017/3/58c26e114/forced-displacementgrowing-colombia-despite-peace-agreement.html>.

92 J. Burke, 'Bonded by spilt blood, South Sudanese refugees in Uganda reach million mark', The Guardian, 17.07.2017, <https://www.theguardian.com/global-development/2017/aug/17/ south-sudan-refugee-families-uganda $>$. 
Myanmar (Burma) ${ }^{93}$ or Australia's highly controversial detention centres in, for example, Papua New Guinea and Nauru. ${ }^{94}$

\section{III.}

The present book is split into three main parts. Part I is entitled The European Integration Project and Irregular Migration: Upholding Fundamental Values and Principles. This volume begins by providing an overview of the regulatory framework for irregular migration currently in place at the supranational level. It highlights the key values and principles enshrined in European law and contrasts them with practice, that is, implementation and enforcement. Therefore, a recurring question that arises in this Part asks to what extent these values and principles and these practices are in conformity.

In Chapter 1, Lonardo uses the current legal framework to question who exactly is responsible for the management of migration: the EU or its Member States? As it is a shared competence, the discourse is split. The author analyses the Draft Articles on Responsibility of International Organizations (DARIO) and shifts away from the understanding that the EU should take responsibility. He purports that responsibility should eventually rest with the Member States. Indeed, the extent to which this is applied in practice can be further seen in the following two chapters.

Miglio pursues, in Chapter 2, an understanding of the governance and management of migration in accordance with the emerging principle of solidarity amongst the EU Member States, and the weight that is afforded to this concept when it comes to the Area of Freedom, Security and Justice (AFSJ). In principle, such solidarity has been forthcoming in a monetary sense. However, a shift towards non-monetary solidarity has not been without opposition from individual Member States, which have made legal challenges to contest the increased focus on the so-called 'fair sharing', which helps to define 'the content of the principle of solidarity in this particular policy area. ${ }^{95}$ Indeed, here a distinction is made between responsibility (cf. Chapter 1) and solidarity, which as previously mentioned, and on this author's view - is increasingly being called upon as a tool for crisis management.

\footnotetext{
93 A. Ramzy, '270,000 Rohingya Have Fled Myanmar, U.N. Says', The New York Times, 08.09.2017, <https://www.nytimes.com/2017/09/08/world/asia/myanmar-rohingya-refugees-270000. html $>$.

94 Human Rights Watch, Australia/PNG: Refugees face unchecked violence: Keeping People on Manus Island Leaves Hundreds at Risk, 25.10.2017, <https://www.hrw.org/news/2017/10/25/ australia/png-refugees-face-unchecked-violence>; cf. also 'The Nauru Files', The Guardian, $<$ https://www.theguardian.com/australia-news/nauru-files $>$. 
Another tool for crisis management is discussed in Chapter 3, where Butler provides an insight into the bilateral measures taken by EU Member States, on behalf of the EU but under the auspices of EU external relations, and in particular the Common Foreign and Security Policy (CFSP). The chapter considers the questionable legality of some of these agreements and demonstrates interconnections between these and the EU-Turkey Statement of 18 March 2016 that further elaborated upon the EU-Turkey Joint Action Plan of 15 October 2015, and its unprecedented presentation as a press release. This inevitably raises questions about the Statement's ability to be overseen judicially and the implications of such an action on the rule of law.

Chapter 4 provides an alternative perspective on migration to the EU, where this phenomenon is not considered as a crisis situation (as it is viewed in the common parlance). Instead, Cudowska argues that migration has been a steady and an unstoppable phenomenon for more than a decade and it has had a clear effect on economies and trade policies across the globe. Nowadays, migration is an unrelenting part of global society and drives social and economic changes.

In Chapter 5, Drinóczi and Mohay discuss the recent case of Ilias and Ahmed $v$ Hungary (2017), in which the ECtHR upheld the protection of the fundamental rights of irregular migrants. The Court found the detention of the two asylum seekers to be arbitrary and that the Hungarian authorities had deprived them of the right to challenge the conditions they were put into. These authors see the Strasbourg Court's decision as a confirmation that 'the existing rights and standards are, in principle, appropriate for the handling of current emergency or crisis situations and no reinterpretation is necessary or warranted. ${ }^{96}$ The authors link the deeds of the Hungarian government with the negative political and social attitude towards irregular migration. To illustrate their point, the authors report on the populist moves of the Hungarian government in place and, as an example, they reproduce the entire text of the 'National Consultation on Immigration and Terrorism' that was run in 2015.

Gabrielsen Jumbert determines, in Chapter 6, the extent to which measures aimed at providing assistance and relief to migrants at sea en route to Europe create, in parallel, a so-called 'pull factor', that is, an encouragement for more migrants to come. The 'fear of saving lives' has been both dominant and powerful in popular perception and in policy debates since it seems to explain 'the otherwise inexplicable. ${ }^{97}$ This resulted in the emergence of controversial deterrent policies, including 'push back' operations, which was met, in response, with rescue operations run by some non-governmental organisations (NGOs). The author eventually asks for a 'broader picture' to be taken into account in the determination of what motivates (or not) migrants to come to Europe.

\footnotetext{
96 Chapter 5, in this volume, p. 110.

97 Chapter 6, in this volume, p. 121.
} 
Part II is entitled Migrants, their rights and the limits thereof. Here the authors analyse whether the very basic concepts on which migration law and policy operate live up to the expectations vested therein nowadays. In particular, these authors ask after the limits of the concept of 'refugee' and the definition of certain crimes related to migration; they further consider how these relate to the values and principles on which Europe has been built.

In Chapter 7, Piekutowska and Kużelewska focus upon the notion of economic refugees and the need to differentiate between those who require humanitarian protection (e.g. as a result of dire economic necessity) and those who qualify as economic migrants (i.e. those seeking improvement of their life economically, but whose choice to migrate has been made rather voluntarily, without the coercion present in humanitarian migration). This Chapter departs from a statistical analysis of international migration and determines the causes and barriers faced by economic refugees. Whilst the authors acknowledge that the impact of economic refugees on the status quo of migration to Europe is rather limited, this phenomenon requires more attention in the context of the EU external relations, especially concerning the regions that are most severely affected by poverty. The authors leave the reader pondering on the limits of the current legal framework, providing for international protection solely to those who are the most vulnerable. Therefore, they stress that economic refugees are not considered refugees according to the Geneva Convention as the decision to leave the country is not based on political persecution, but rather on economic factors. It thus seems that the 1951 Refugees Convention does not entirely correspond to the current migratory needs.

Chapter 8, the first to deal with the criminalisation of migration, looks at the EU response to the smuggling of migrants. Brière commences by comparing the EU definition of this crime with its counterpart in international law. She discusses how legislators decide to define the offence of migrant smuggling and how their decisions may encroach upon democratic principles. The author underlined conflicting perceptions and arguments within both the EU and its Member States.

In Chapter 9, Top discusses the legal evolution of the so-called political offence exemption in extradition law. The author discusses the legal developments made in relation to terrorism and the impact that these have had not only on the attitude towards migrants arriving in Europe, but also on the legitimacy of the European integration project, where values such as 'respect for human dignity, freedom, ... equality, ... human rights, including the rights of persons belonging to minorities' 98 are put into question. 
Part III is entitled The status quo of migration in Europe: selected national perspectives and moves the focus of this book from the European to a national level. These chapters do not only act as 'national reports' but they also demonstrate how various stakeholders, working at a national level, deal with irregular migration. The latter is of crucial importance as migration policy is a shared competence between the EU and its Member States; this part provides an insight into some of the unilateral measures implemented by Member States to regulate and manage migration.

Chapter 10 provides an overview, portrayed by Panzeri, of the Italian response to the migrant 'crisis'. The author focuses on Italian legislative developments regarding migrants' reception and integration. He criticises the lack of solidarity among the EU Member States, especially from the Visegrád Group, ${ }^{99}$ which is leading in populism, instead of a rational migrant policy. The author also notes obvious shortcomings regarding Italian and European management of the 'migrant crisis'. He eventually criticises the insufficient measures of social inclusion addressed to irregular migrants in Italy.

Chapter 11 addresses the criminalisation of migration at a national level. Perkowska elaborates upon the 'crimmigration' - the interception of criminal and immigration law - that is a central feature of current migration law in Poland and its reforms in the past decade. This has led to some disproportionality in the response towards the status quo of migration, premised upon the perceived threat to public order and security. However, the Chapter clearly demonstrates that such reforms are a necessary step towards the harmonisation and approximation of national law with EU law. Yet the Chapter thought-provokingly engages with controversial domestic legal reform that is merely proscribing democratic standards and encourages 'crimmigration'. In result, the effective protection of fundamental rights has been put into question.

In Chapter 12, Roots discusses a new stakeholder in the governance and management of migration: NGOs. She suggests their involvement owes much to the inefficiency of the way in which irregular migration has been handled thus far. In her chapter, she considers the involvement of these organisations at a national level in the development of the Estonian migration policy. The author outlines the key attributes of NGOs that are necessary to ensure that civil society participation is effective. She subsequently evaluates the actual impact these organisations have had in the Estonian context against the backdrop of the current migration situation in Europe. She also notes that the involvement of NGOs began in 2013, which demonstrates an ongoing engagement with legal and policy development that pre-dates the current situation.

99 Cf. supra n. 42. 
Finally, in Chapter 13, Sierocka discusses language as a significant factor contributing towards the integration of migrants into their host polities. She stresses that linguistic integration is a key response when combatting the hostile and populist discourse against irregular migrants. In her Chapter, she describes the existing European and national responses to linguistic integration and concludes that it is, more than ever, vital that Europeans engage in a 'dialogue' with irregular migrants in order to positively affect social cohesion and integration of immigrants into host societies.

\section{IV.}

Taking into account the topics discussed in the contributions to this volume, we cannot help but offer in the following a few points of reflection on irregular migration to Europe. Building on the past and the present of migration, here we focus - perhaps more importantly - on its future.

1. Migration is quite like the weather. Migration is nothing new: it has been here and there in the past, it is a phenomenon of the present times and it will never cease to occur, regardless whether we like it or not. (And, as some predict, because 'as intercountry inequality widens and climate change threatens livelihoods', the numbers of migrating people will only increase. ${ }^{100}$ Neither is migration limited to Europe; quite the contrary: all parts of the world have faced it. Consequently, we see the weather (sic!) as an apt allegory for migration. Migration, similarly to the weather, has always been here.

To further illustrate the omnipresence of migration, and in line with the tradition that European Integration and Democracy book series has established, we have reproduced on the front cover of this volume - with the kind permission of the Art Gallery of New South Wales in Sydney, Australia - one of the masterpieces of Jeffrey Smart (1921-2013), titled Bus Terminus (1973). ${ }^{101}$ In this modernist picture, these buses - of various shapes and colours - have either just completed their journeys or they wait to embark on some other. We do not know where these buses have come from and where they soon might go. We know nothing about their passengers and their luggage - if there are few or many of them, what motivates them to go, whether their journey is comfortable enough, if someone awaits them, etc. Yet one thing is sure: these buses have been carrying people and will not cease to do so. The same can be said about migration.

100 I. Goldin, G. Cameron and M. Balarajan, Exceptional People: How Migration Shaped Our World and Will Define Our Future, Princeton University Press, Princeton 2012, p. 6.

101 J. Smart, Bus terminus, 1973; Art Gallery of New South Wales, Sydney, Australia; No. 251.1998, 92.0 x $81.0 \mathrm{~cm}$; copyright by Estate of Jeffrey Smart, <https://www.artgallery. nsw.gov.au/collection/works/251.1998>. 
2. Migration - as an unavoidable fact of life and like many aspects of public life - requires both responsible and visionary governance and management. ${ }^{102}$ Many meanings can be asserted to these qualifying terms, yet in the context of migration, we would like to point out a few characteristics thereof.

$2 a$. The first step is perhaps to realise the unavoidability of migration and, as a consequence, to start responding thereto. As we have suggested, migration is quite like the weather, yet while people cannot do much about the weather, they could - and should - do something about migration. ${ }^{103}$ Thus we agree with Patrick Kingsley that ' $\mathrm{t}$ ] he sooner we recognise the inevitability of this movement, the sooner we can try to manage it.' ${ }^{104}$ François Crépeau, the UN Special Rapporteur on the human rights of migrants, added '[a]s mobility is increasing with globalisation, instead of resisting it, we should organise it.' ${ }^{105}$ The simplest way is to organise channels for legal migration, as, for example, with the Hungarians after the Budapest Revolution in $1956^{106}$ or with the Indochinese in late 1970s. ${ }^{107}$ Thus, Jean-Claude Juncker announced in his 2017 State of the Union Address that ' $[w]$ e will also work on opening up legal pathways. Irregular migration will only stop if there is a real alternative to perilous journeys.' ${ }^{108}$

$2 b$. Yet having the mere governance and management of migration in place is not sufficient. This governance and management has to adhere to certain qualities - in our view: responsibility and vision. Responsible governance and management adheres, at minimum, to democratic standards, the rule of law (Rechtsstaat) and respect for human rights. Migrants are human beings and

102 We distinguish between 'governance' and 'management'. Simplifying, the former signifies leadership, policy-making, regulation, etc. The latter comes second and implements such 'governance' into practice.

103 We have been inspired here by Gary T. Marx. In early 2010s, he compared privacy to the weather and argued that - contrary to the weather - 'there is much that should, and can, be done' about the governance and management of privacy. G.T. MARx, 'Privacy Is Not Quite Like the Weather' in D. Wright and P. De Hert (eds.), Privacy Impact Assessment, Springer, Dordrecht 2012, p. v.

104 P. KingsLey, supra n. 79, p. 264.

105 G. JACKson, 'UNs François Crépeau on the Refugee Crisis: 'Instead of Resisting Migration, Let's Organise It", The Guardian, 22.04.2015, < https://www.theguardian.com/world/2015/ apr/22/uns-francois-crepeau-on-the-refugee-crisis-instead-of-resisting-migration-letsorganise-it $>$.

106 M. ZIECK, 'The 1956 Hungarian Refugee Emergency, an Early and Instructive Case of Resettlement' (2013) 5(2) Amsterdam Law Forum, <http://amsterdamlawforum.org/article/ viewFile/314/487>; K. Kovačević, 'The Refugee Problem in Yugoslavia', in: J.M. RaIner, K. Somlai (eds.), The 1956 Hungarian Revolution and the Soviet Bloc Countries: Reactions and Repercussions, The Institute for the History of the 1956 Hungarian Revolution, Budapest 2007, pp. 111-128, <http://www.rev.hu/rev/htdocs/hu/kiadvanyok/Hungarian_revolution_2007/ The_1956HungarianRev.pdf $>$.

107 B. STEIn, 'The Geneva Conferences and the Indochinese Refugee Crisis' (1979) 13(4) The International Migration Review 716.

108 J.C. Junker, State of the Union Address, Strasbourg, 13.09.2017. 
hence holders of inalienable rights, and Europe, like many other democratic polities, has promised to respect them.

All European countries and the EU itself, each have their magnae cartae and each promised to live up to their commitments therein; as we outlined at the beginning of this contribution. They promised to respect human rights of 'everyone within [their] jurisdiction. ${ }^{109}$ The European Court of Human Rights in Strasbourg has emerged as the ultimate guardian of these commitments - as Drinóczi and Mohay observe - as the many polities in Europe have failed to do so. We thus argue even further: compliance with international human rights law is indispensable, but more is needed. The stakes here are rather high: migrants are human beings (a repetition, we know) and, if they are refugees, their life is often in peril. Therefore this compliance with the highest legal norms, we argue, must be complemented by an ethical reflection.

There are 'big' ethical dilemmas that both individuals and those who govern them must ask themselves. For the latter, the main question would ask what constitutes a good government. How should a just government act? Should such a government take moral responsibility for the well-being of refugees? Would the acceptance of irregular migrants be one of Aristotelean virtues? Is a good government bound by a duty to help? Taking a utilitarian stance, should those who govern strive only for the greater good for their own people or, rather, should they strive for the entire humankind? (In contrast, those who want to reject refugees often adopt similar arguments and claim that welcoming refugees would result in a reduction of their own 'good'.) ${ }^{110}$ The answer to each of these questions depends on the ethical stance chosen by the individual and those who govern and manage the polity; we outlined this earlier in our discussion on ethics and migration.

To solve such a dilemma, Europe could ask itself what we call a kind of 'reversed democracy question'. ('Reversed' because now it is Europe who is being asked for help. In the future, the situation might reverse: Europe might ask for help.) This is an inquiry that Bentham and Mill perhaps would embark on too. If, for instance, a humanitarian crisis hit Europe and forced thousands or millions of Europeans to flee the Old Continent in a quest for survival, what would Europe want the other democratic countries around the world to do? Would it want them to build fences with barbed wire and keep Europeans in refugee camps for months, if not years? Or would Europe want these countries built equally on the respect for human dignity and governed by democracy, rule of law (Rechtsstaat) and the respect for fundamental rights - to stick to these values and principles?

\footnotetext{
109 Convention for the Protection of Human Rights and Fundamental Freedoms, supra n. 44, Art. 1.

110 We thank Iris Huis in 't Veld for bringing this matter to our attention.
} 
Another way could be to ask what does Europe owe to refugees. Harpviken speculated that Angela Merkel would be awarded the Nobel Peace Prize for 2015 as she had demonstrated a 'true leadership and risen above politics, taking a humane approach in a difficult situation'111 with her opening of German borders for irregular migrants in 2015. Merkel perhaps asked herself a few questions Kant would have asked himself: is it a moral duty to treat everybody with respect? Should we show some sincere solidarity with fellow human beings? Should we treat all people as an end in themselves and not merely as a means to some end? Or should we allow robbing them of their dignity?

Furthermore, ethical reflection requires also thinking about more practical aspects. First and foremost, ethics goes beyond the law and ethical reflection asks an elementary question after the contents of the law. It was observed already in ancient Rome that non omne quod licet honestum est. ${ }^{12}$ For example, should the law differentiate between vulnerable and non-vulnerable migrants? What constitutes a good cause for fleeing a collapsed homeland to be accepted in a host polity? Is fleeing a war a better reason than fleeing dictatorships, religious extremism or poverty? Is a child or a pregnant woman a more vulnerable migrant than any other migrant?

In this ethical reflection, a few chapters in this volume analysed criminal justice aspects and the allocation of responsibility (Briere, Top and Lonardo). We would point out one more issue. Those who unjustifiably act against migrants shall face liability for their deeds and criminal law must be apt to address these crimes. In this context, we can immediately think of human smuggling and trafficking, but the picture is actually much broader. For example, Kalpouzos and Mann pointed out to the 'banality of crimes against migrants', as '[a]round the world, migrants are locked up in camps, abused and often driven to the brink of starvation. Many die as a result.' ${ }^{\prime 13}$ Therefore it is not surprising that the International Criminal Court and its Prosecutor have been asked to examine the alleged 'migrant-related crimes in Libya'114 or to 'launch an investigation

111 Peace Research Institute Oslo, 'Nobel Peace Prize 2015: PRIO Director's Speculations', October 2015, <https://www.prio.org/About/PeacePrize/PRIO-Directors-Speculations-2015>. Eventually, the Prize was awarded to the Tunisian National Dialogue Quartet. Cf. 'The Nobel Peace Prize 2015'. Nobelprize.org, press release, <http://www.nobelprize.org/nobel_prizes/ peace/laureates/2015/press.html>.

112 Latin for 'not all that is permitted is honest'.

113 I. Kalpouzos and I. MAnN, 'The Banality of Crimes against Migrants', Der Spiegel, 28.10.2017, <http://www.spiegel.de/international/world/editorial-on-crimes-against-migrants-a1175239.html>.

114 International Criminal Court, 'Statement of the ICC Prosecutor to the United Nations Security Council on the situation in Libya', New York, 09.05.2017, \$29, <https://www.icc-cpi. int/Pages/item.aspx?name $=170509$-otp-stat-lib $>$. 
regarding crimes against humanity which may have been committed against asylum seekers and refugees in Nauru and Manus Island.' ${ }^{115}$

In parallel, the needs of asylum seekers and refugees are not limited to their most basic needs, especially to the respect for their dignity and fundamental rights. There have some rudimentary needs too. They need to live as normally as possible and thus - as Cudowska pointed out - they need access to the labour market. They too need integration with the hosting polity (as Panzeri argued) and the acquisition of language skills (as Sierocka asserted) - as well as access to education - constitute perhaps the first steps thereto. ${ }^{116}$ By contrast, the hosting polity also has its own needs that are of ethical importance, for example, how to ensure safety and security for everyone?

2c. Responsible governance and management of migration, which is a global phenomenon, requires coordinated answers. It was Beck who famously observed that 'global risks require global responses' and no country could cope alone which such challenges. ${ }^{117}$ Migration is such a 'global risk' and Harpviken strikes the same chord by arguing that migration 'necessitate[s] transnational solutions.'118 In the context of Europe, what is clear is that there needs to be consistency in the response towards irregular migrants. Indeed, whilst the Dublin system is considered as the 'baseline' approach to asylum in the EU, it cannot but be noted that both its design and implementation are questionable. ${ }^{119}$ Its application is doomed either way: either acceptance of EU rules will lead to the overburdening of Southern EU Member States or ignorance of EU rules will lead to the overburdening of Northern EU Member States. ${ }^{120}$ Furthermore, the governance and management of migration requires cooperation and solidarity. We do not only mean that the EU Member States should cooperate and mutually support each other in governing migration, financially and politically (as required per the Treaties and as Miglio discussed), but also, in its daily management multiple stakeholders, from public authorities to NGOs (as Roots suggests), should be involved and should cooperate and mutually support each other.

115 'The Situation in Nauru and Manus Island: Liability for crimes against humanity in the detention of refugees and asylum seekers', communiqué to the Office of the Prosecutor of the ICC, 13.02.2017, <http://docs.wixstatic.com/ugd/b743d9_e4413cb72e1646d8bd3e8a8c9a466950. pdf $>$.

116 For example, the VUB since 2016 maintains the 'Welcome Student-Refugee Program'. For those who had to 'abruptly stop their studies and flee', the University wants to give them a 'fair chance to continue their studies'. Cf. <http://www.vub.ac.be/en/welcome-student-refugeesprogramme $>$.

117 U. BECK, 'The Cosmopolitan Condition: Why Methodological Nationalism Fails' (2007) 24(7) Theory, Culture \& Society 288.

118 K.B. Harpviken, Foreword, in this volume, p. viii.

119 European Parliament, Reform of the Dublin System, briefing No. PE 586.639, 10.03.2017.

120 F. Trauner, supra n. 88. 
However, we acknowledge there is also a negative side of migration. We have already mentioned a widespread argument that migration might not only bring profound changes to the society but also, in some instances, the migratory process could lead to a security threat. This matter has been frequently discussed in this volume. However, both the governance and the management of such a situation call for putting a 'thin red line' between benefits and threats posed by migration. This could take a form of the classically understood legal concepts of 'proportionality' - that is, legitimately and not excessively justifying any interference with a fundamental right ${ }^{121}$ - or 'practical concordance' (praktische Konkordanz) - that is, preserving as much as possible of each competing interest at stake. ${ }^{122}$ Yet, whenever the existence of a threat posed by irregular migrants cannot be satisfactorily established, the law already knows the solution: in dubio pro reo.

$2 d$. We further argue that visionary governance and management of migration is needed. The measures taken now to address migration will impact on future generations. The entire body of migration law and policy was conceived in the aftermath of military conflicts in Europe in the twentieth century, with a particular cause for migration in mind: fleeing a war. Thus, it is often called an 'antiquated refugee regime. ${ }^{123}$ Yet the governance and management of migration, in the same way as many aspects of public life, face changes in the society and thus must be responsive thereto. We have hinted at this already and we can take it for granted that the future will bring more examples of so-called 'survival migration.' ${ }^{124}$ This requires thinking about the future in a long term and refraining from ad hoc, quick and thus incompetent responses. Harpviken calls for 'informed political innovation'. A few authors in this book have discussed some brave proposals: from a simple need for long-term solutions, to an addressing of the root causes of irregular migration (Butler); and from the establishment of a centralised procedure for examining asylum claims in the EU (Miglio); to a re-definition of basic concepts such as 'refugee' (Piekutowska and Kużelewska); and migration-related crimes (Brière, Top). Furthermore, New Zealand's incoming Labour-led coalition government has already hinted at the introduction of an experimental humanitarian visa category for those

121 Cf. D. Lindsay, 'The Role of Proportionality in Assessing Transatlantic Flows of Personal Data', in D.J.B. Svantesson and D. Kloza (eds.), Trans-Atlantic Data Privacy Relations as a Challenge for Democracy, Intersentia, Cambridge 2017, pp. 49-84.

122 O. De Schutter and F. Tulkens, 'The European Court of Human Rights as a Pragmatic Institution' in E. Brems (ed.), Conflicts Between Fundamental Rights, Intersentia, Antwerp 2008, pp. 169-216.

123 J. Ramji-Nogales, supra n. 75.

124 A. Betrs, Survival Migration: Failed Governance and the Crisis of Displacement, Cornell University Press, Ithaca 2013. 
who are adversely affected by climate change. ${ }^{125}$ We thus argue for the need for migration law to adapt to the reality of changing society, regardless whether at a national, supranational or international level. It is perhaps for these reasons that the UN is currently considering two new 'global compacts' on migration, one on refugees and the other on safe, orderly and regular migration, both of which are to be adopted in 2018. ${ }^{126}$ Yet we acknowledge that the difficulty of adhering to these qualities of governance and management of migration i.e. being responsible and visionary - is magnified by the importance of the human lives at stake, the profound uncertainty of the consequences of migration and its omnipresence.

3. However, thus far, the way in which Europe has managed the influx of irregular migrants has created multifaceted crises. We agree with Kingsley that this migration situation is 'predominantly a problem with Europe, not with the people trying to breach its borders. ${ }^{127}$ Many of the authors in this book have highlighted the incompetence and inadequacy of European and national responses to the migration crisis - especially their fragmented, improvised and chaotic characterand perhaps most acutely Panzeri with his snapshot of migration governance in Italy. In conclusion, both the EU and some of its Member States have, at times, encountered troubles with conforming to democratic standards, the rule of law (Rechtsstaat) and the protection of fundamental rights.

In an attempt to adequately name this problem, many commentators have called it a migration 'crisis' and highlighted the sense of urgency. Yet this crisis is multidimensional, having at least four aspects. ${ }^{128}$ Indeed, if we look narrowly, it is a 'refugee crisis', having a predominantly political and legal nature, and caused by, for example, the narrow understanding of international refugee law (e.g. including in its scope the escape from persecution, but excluding the e.g. 'survival' migration or economic refugees), the lack of coherence in the EU migration and asylum policy (e.g. shared responsibility between the EU and its Member States), or the lack of 'extraterritoriality' of refugee law (which requires those who need protection to have already accessed the territory of a country whose help they seek, rather than to be offered safe and regular channels for

125 Ch. Anderson, 'New Zealand considers creating climate change refugee visas', The Guardian, 31.10.2017, <https://www.theguardian.com/world/2017/oct/31/new-zealand-considers-creatingclimate-change-refugee-visas $>$.

126 United Nations, Report of the Special Rapporteur of the Human Rights Council on extrajudicial, summary or arbitrary executions, New York, 15.09.2017, A/72/335, \$\$4 and 84.

127 P. Kingsley, supra n. 79, p. 294.

128 We thank Marta Pachocka for bringing this matter to our attention. Cf. further M. PACHOCKA, 'Looking beyond the current migration and refugee crises in Europe: a common policy of the EU and the outlook for the future - in search of solutions' in Migrations: Jean Monnet Seminar 2016, Publications Office of the European Union, Luxembourg 2016, pp. 73-84. 
reaching such a country). ${ }^{129}$ Second, it is an '(im)migration crisis', having rather demographic nature, caused by the massive number of irregular migrants ante portas and bringing 'consequences ... for the transit and migrant-receiving countries. ${ }^{130}$ Third, it is a 'humanitarian crisis', due to the perilous journeys that the irregular migrants undertake, often resulting in death, as well as due to the reasons therefor, such as fleeing war-torn and impoverished countries. Fourth, in a broader sense, it is a 'solidarity crisis' between the European countries, wherein the political wrangling and lack of reciprocity has led to a 'divided Europe' and no real and effective system of 'fair-sharing of responsibility' (cf. Lonardo, Miglio and Butler).

However, the perception of irregular migration as a threat must be contextualized. Not all European countries have been equally affected by irregular migrants; there are countries of first-reception (e.g. Greece and Italy), from which irregular migrants transit - via, for example, Hungary - to target countries (e.g. Germany or Sweden); some countries seem not to be affected at all (e.g. some Baltic States). In other countries there have been wide-reaching legal reforms that are being attributed to a threat that is not so evident, as Perkowska demonstrated in the Polish context.

The EU has sought to overcome many obstacles it has faced by deepening its integration towards 'an ever closer Union," ${ }^{131}$ often on a paradigm 'crisis as an opportunity'. Miglio takes the most recent example of the sovereign debt crisis. A response thereto saw many initiatives adopted at multiple levels that have sought to strengthen and facilitate the stability of the monetary union. For instance, the euro crisis resulted in the creation of new, and a strengthening of existing, supranational institutions such as the European Stability Mechanism, the enhancement of fiscal surveillance powers of the Commission, and the construction of the banking union. ${ }^{132}$ Nevertheless, approaches to tackling a common migration and asylum policy are inevitably more complex and sensitive processes than those that created the monetary union. What can be seen from the recent migration 'crisis' is that Europe nowadays resists, to a large extent, supra-national decision-making and that it is rather more polarised than any more integrated as 'for every effort that fails, the divide grows wider.' ${ }^{133}$

Notwithstanding, migration is a dynamic process and its responsible and visionary management and governance is shaped by experience. The current migration situation offers a valuable lesson to be learnt quickly.

\footnotetext{
129 J. Ramji-Nogales, supra n. 75.

130 M. PACHOCKA, supra n. 128, p. 74.

131 D. Dinan, Ever Closer Union: An Introduction to European Integration, 4th ed., Lynne Rienner Publishers, Boulder 2010.

132 T.A. Börzel and T. Risse, 'From the Euro to the Schengen Crises: European Integration Theories, Politicization, and Identity Politics' (2018) 25(1) Journal of European Public Policy 1.

133 K.B. Harpviken, Foreword, in this volume, p. ix.
} 
4. A responsible and visionary governance and management of migration requires, at minimum, 'best available information' and a debate carried out in moderation. Both public debate and policy-making run on information, be it information sought for a discourse and to make decisions, and information disseminated in order to influence such a discourse and decision-making. ${ }^{134}$ For such information to support responsible and visionary governance and management of migration, it has to satisfy a few quality criteria.

It will sound like a truism, but debates and decision-making that are not based on facts, that is, information that is 'known or proved to be true,' ${ }^{135}$ and that are not based, as far as possible, on 'best available information' would create only confusion and bring bad results. We are fully aware that a 100 per cent certainty is unachievable, yet it is an ideal to which debates and decision-making should aspire. We have attempted to demonstrate these tensions at the beginning of our contribution and the many authors in this book have analysed them in a greater detail. Perhaps the prime example from the present book would be the concept of 'rescue as a pull-effect' that, in the words of Gabrielsen Jumbert, 'allows a seemingly logical explanation to the otherwise inexplicable' and hence remained 'powerful', guiding 'official responses to the crisis'.

The 'best available information' implies - as far as possible - the need for a complete picture. Therefore we argue for a more holistic approach to the governance and management of migration, in order to encompass many different, inevitable perspectives and understandings that are sometimes lacking in rather narrowly focused or one-sided approaches. This is clearly visible when Piekutowska and Kużelewska consider the concept of 'economic refugees', when Brière analyses the difficulties with defining the crime of 'migrant smuggling', or Top discusses the 'political offence' exemption in extradition law.

Yet plain facts do not always speak to popular imagination. It is difficult to understand what migrants are going through without meeting them, or without seeing the places they are fleeing from or without paying a visit to the places where they have been forced to live, such as refugee camps or detention centres. We argue for going beyond media coverage. Especially for those concerned with policy-making, we suggest a retrospective visit, for example, to Sarajevo in contemporary Bosnia and Herzegovina to better understand what its inhabitants went through barely a quarter of century ago, just on the doorstep of the European integration project, and why some of them wanted to flee. ${ }^{136}$ For those less inclined to travel, we suggest reading some of the voluminous accounts of post-2010 refugees' journeys. ${ }^{137}$

134 C.C. Hood, supra n. 38, pp. 21-39.

135 Oxford Dictionary of English, 3rd ed., Oxford University Press, Oxford 2010.

136 M. Glenny, The Balkans: Nationalism, War, and the Great Powers, 1804-1999, Penguin, New York 1999.

137 Cf. e.g. P. Kingsley, supra n. 79; A. BJörk and M. Beijmo, Båt 370. Döden på Medelhavet, Norstedts, Stockholm 2017. 
Eventually, as Harpviken puts it, migration requires intellectual and ethical honesty'138 and this equally applies to the debates thereon. We propose this in contrast to the contemporary quality of this discourse, rather full of misleading statements and too much (negative) emotion. ${ }^{139}$ The media, to a large extent, control the circulation of information and one of the greatest sins of some but not all - of the media outlets is the inaccurate portrayal of migrants and, correspondingly, of the risk of a threat to public security and safety. By increasing their subjectivism and the pursuit of income, these media are congruently losing their function in a democratic polity, which, in turn, creates only an 'illusion of the fourth estate. For example, in some European countries, due to the media influence - and in particular in rural areas where only the public media could reach - the term 'migrant', while semantically a neutral term, nowadays provokes only negative connotations and the popular attitude towards irregular migrants has quickly shifted from acceptance towards strong opposition (cf. Drinóczi and Mohay). ${ }^{140}$ This observation is valid not only for 'traditional' media, such as the printed press or television, but also for 'new' ones, including social media sites. Yet it is edifying that some steps have been undertaken to restore public trust in the media, for example the 2016 Code of Conduct on illegal online hate speech, endorsed by the European Commission and four major technology companies from the Silicon Valley. ${ }^{141}$ (Yet we refrain here from assessing its effectiveness.) We therefore suggest that some media outlets should ask their reporters and commentators to revisit a textbook to journalism ethics and standards.

5. A direction to go. All in all, there are irregular migrants standing ante portas of Europe. And this Europe finds itself on the crossroads and asks, like Alice to paraphrase Carroll from the epigraph, 'which way I ought to go from here?'. Indeed, it 'depends a good deal on where [it] want[s] to get to'. If Europe does not 'much care', or does not want to care, for the values and principles it chose to be built on, for responsible and visionary governance and management of public affairs, including (irregular) migration, for its legitimacy and reputation, then, as the Cheshire Cat hints, 'it doesn't matter which way [it] go[es]', even though it might ultimately get 'somewhere'. A crisis provoking another crisis is just 'some' solution, but it would not be a preferable one. (This observation is also valid for many other polities around the world that have been concerned

\footnotetext{
138 K.B. Harpviken, Foreword, in this volume, p. v.

139 BBC, Reality Check: Migration to the UK, 25.05.2017, <http://www.bbc.com/news/ election-2017-40015269>.

140 We thank István Hegedüs for bringing this matter to our attention. Cf. e.g. A. FöLdEs, 'The villagers were so horrified of the refugees that they even banished their mayor', index.hu, 05.10.2017, <https://index.hu/mindekozben/poszt/2017/10/05/ocsenyi_videonk_angolul_is_ the_villagers_were_so_horrified_of_the_refugees_that_they_even_banished_their_mayor $>$. European Commission, European Commission and IT Companies announce Code of Conduct on illegal online hate speech, press release, Brussels, 31.05.2016, IP/16/1937.
} 
with the governance and management of migration.) Therefore, the main aim of our book was to join the voluminous professional and academic literature on migration and to offer a few modest suggestions regarding the direction in which Europe should go whenever irregular migrants stand ante portas.

\section{V.}

This book constitutes the fifth volume in European Integration and Democracy Series. The Series was launched in 2011 and is edited at the Centre for Direct Democracy Studies (CDDS) at the University of Białystok, Poland. Since 2014, the Series has been published by Intersentia, a reputable publishing house based in Belgium and the UK. Each volume in the Series tackles a pressing issue that is of utmost importance for the European integration project and, at the same time, that poses a challenge to the values and principles on which this project has been built. Because our books are titled in fine '... as a challenge to democracy', we hasten to explain that, for this Series, we see the term 'challenge' rather neutrally. We approach each subject-matter as a 'task or situation that tests someone's abilities'142 and not necessarily as something negative, especially as a threat to broadly understood democracy. Thus far, our books have discussed through that lens - topics such as the elections to the European Parliament or trans-Atlantic data privacy relations. ${ }^{143}$

As all volumes thus far in our Series, this book originated from a call for papers, which we issued in May 2016. The response we received was indicative of the topicality of our chosen subject-matter and the variety of interest from academic scholarship. All submissions underwent a double-blind peer-review process in accordance with the Guaranteed Peer-Review Content (GPRC) scheme, a standard used by Intersentia. ${ }^{144}$ In result of this careful selection process, we have accepted 10 submissions. We have subsequently enriched the contents of the volume with three invited contributions from prominent scholars and commentators.

This book does not aspire to be a monograph on irregular migration to Europe; it is, rather, an anthology compiling diverse yet rich academic comments

\footnotetext{
142 Oxford Dictionary of English, supra n. 135.

143 The previous volumes are: E. Kużelewska and D. Kloza (eds.), The Challenges of Modern Democracy and European Integration, Aspra-JR, Warsaw 2012; E. KużelewsKA and D. Kloza (eds.), Elections to the European Parliament as a Challenge for Democracy, AspraJR, Warsaw 2013; E. Kużelewska, D. Kloza, I. Kraśnicka and F. Strzyczkowski (eds.), European Judicial Systems as a Challenge for Democracy, Intersentia, Cambridge 2015; D.J.B. Svantesson and D. Kloza (eds.), Trans-Atlantic Data Privacy Relations as a Challenge for Democracy, Intersentia, Cambridge 2017.

144 Cf. <http://www.gprc.be/en/content/what-gprc>.
} 
on a wide range of pressing issues within a broad topic. (We acknowledge there are issues we would have liked to see discussed in this volume, yet - due to the chosen format, i.e. chapters deriving predominantly from a call for papers - we have not received, even for consideration, any contribution devoted thereto. $)^{145}$ We have been exceptionally careful in allowing the authors to express their ideas as they want to do so, with only minimal editorial intervention. We wish for this book to be both a commentary and reference work, and to reach not only our fellow academics in Europe and beyond, but also policy makers, civil society organisations and journalists concerned with (irregular) migration.

VI.

Many have helped in the gestation of this book and in ensuring its quality. In particular, we thank the authors as well as congratulate them for their strong academic scholarship, which has been further bolstered by the apt and thought-provoking Foreword. For that, our gratitude and thanks go to Kristian Berg Harpviken, Research Professor, and former Director, of the Peace Research Institute Oslo (PRIO). We thank the anonymous peer-reviewers who have all contributed to ensuring the scientific quality and integrity of this volume. We are grateful to the panellists and participants of the policy forum Migration crisis as a challenge for democracy, held on 14 November 2017 at the University of Warsaw and co-organised by the CDDS; their interventions gave us further impetus and ideas to refine the present Introduction. We have received with gratitude further help from - in alpha order - Rocco Bellanova, Karolina Boiret, István Böröcz, Raphaël Cahen, Iris Huis in 't Veld, Lucas Melgaço, Marta Pachocka, Sibel Top, Florian Trauner and Marta Witkowska. Once again, we thank Intersentia and our publisher Tom Scheirs. (It is our third book together!) Finally, we gratefully acknowledge the intellectual and financial support received for this book from the Research Group on Fundamental Rights and Constitutionalism (FRC) at the Faculty of Law and Criminology of the Vrije Universiteit Brussel (VUB).

Białystok/Brussels, November 2017

145 The issues include, inter alia, the role of new technologies in migratory processes and the position of various religious groups on irregular migration. 



\section{CONTENTS}

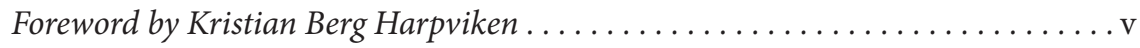

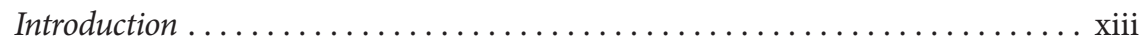

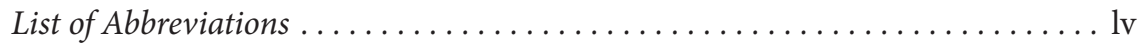

\section{PART I}

THE EUROPEAN INTEGRATION PROJECT AND IRREGULAR

MIGRATION: UPHOLDING FUNDAMENTAL VALUES AND

PRINCIPLES

\section{The 'Migrant Crisis': Member States' or EU's Responsibility?}

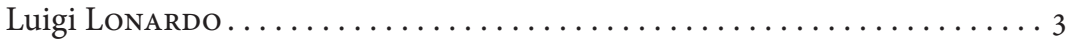

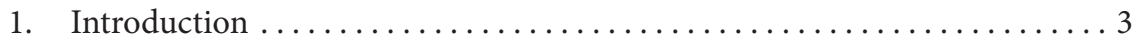

2. International Law Obligations $\ldots \ldots \ldots \ldots \ldots \ldots \ldots \ldots \ldots \ldots \ldots \ldots \ldots \ldots \ldots \ldots \ldots$

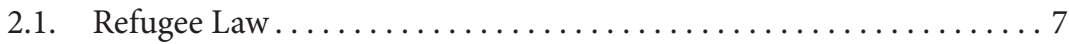

2.2. Law of the Sea ............................. 10

3. Member States' Practice - Search and Rescue, Border Controls

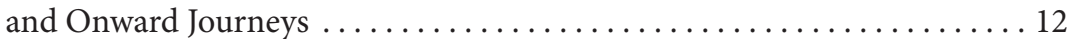

4. Responsibility of the EU or of the Member States? ............. 15

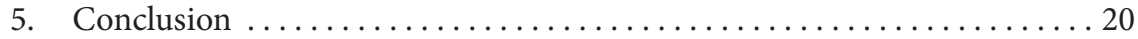

2. Solidarity in EU Asylum and Migration Law: A Crisis Management Tool or a Structural Principle?

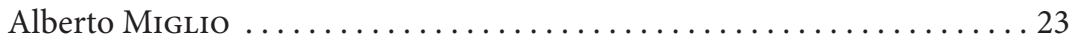

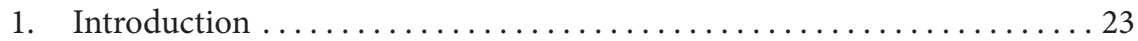

2. Solidarity in the Treaties: The Gradual Emergence of a Legal Principle. . . . 25

3. 'Solidarity': What's in a Name? . . . . . . . . . . . . . . . . . . . . 29

4. Responsibility and Solidarity in the Economic and Monetary Union . . . . 32

5. Solidarity as a Guiding Principle of EU Migration and Asylum Policies . . 36

6. The Common European Asylum System and the Unfulfilled Promise of Solidarity . . . . . . . . . . . . . . . . . . . . . . . 38

7. Conclusion: Is an Alternative Approach Possible?. . . . . . . . . . . . . . 47 
3. EU Foreign Policy and Other EU External Relations in Times of Crisis: Forcing the Law to Overlap?

Graham ButLer.............................. 51

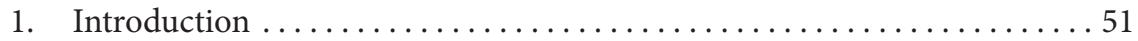

1.1. Problematising Law and Migration $\ldots \ldots \ldots \ldots \ldots \ldots \ldots \ldots \ldots \ldots \ldots \ldots \ldots \ldots$

1.2. Issues at Stake. . . . . . . . . . . . . . . . . . . . . 53

2. Responses to the Migration Crisis in Context ............... 54

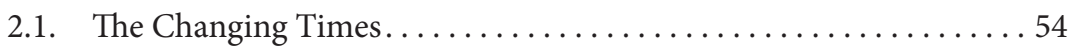

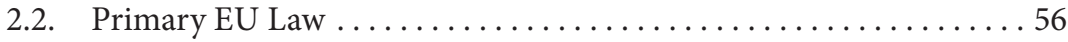

2.3. Bases of Law ............................. 58

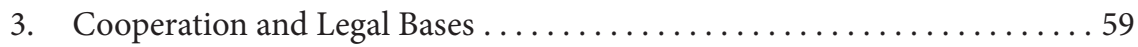

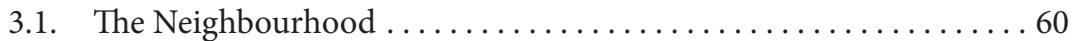

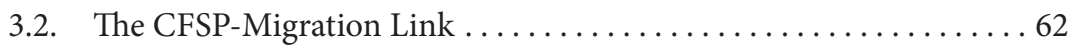

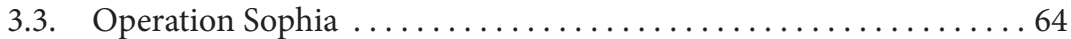

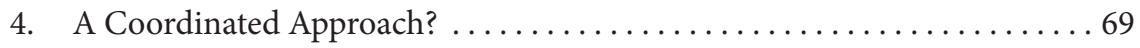

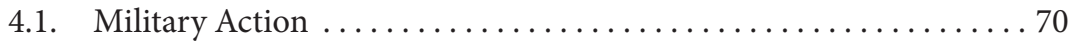

4.2. The Largest Neighbour . . . . . . . . . . . . . . . . . . . 71

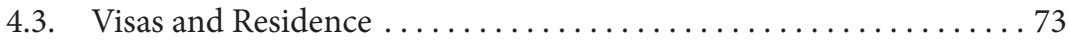

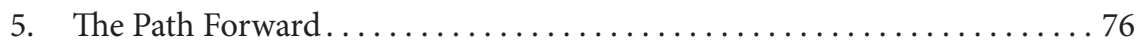

5.1. Chasing the Present. ........................... 77

5.2. Forging Legal Change . . . . . . . . . . . . . . . . . . 79

5.3. Building European Legal Heritage $\ldots \ldots \ldots \ldots \ldots \ldots \ldots \ldots \ldots$

4. The Migration Crisis in Europe: The Implications for Trade and Labour in a Globalised Context

Maria Cudowska................................... 83

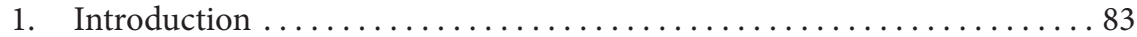

2. Trade and Migration: A Historical Overview. . . . . . . . . . . . 85

3. The Effects of Development on Migration $\ldots \ldots \ldots \ldots \ldots \ldots \ldots \ldots$

4. Migration in the EU: Freedom of Movement. . . . . . . . . . . . . 90

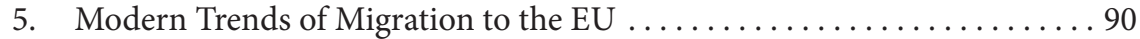

6. Direct and Indirect Effects of Immigration on Economic Growth . . . . . . 93

6.1. Labour Markets ............................ 93

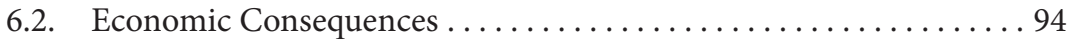

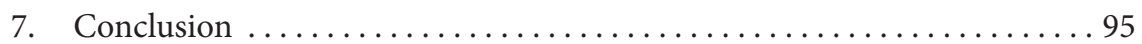

5. Has the Migration Crisis Challenged the Concept of the Protection of the Human Rights of Migrants? The Case of Ilias and Ahmed v. Hungary (Invited Contribution)

Tímea Drinóczi and Ágoston MoHAY................... 97

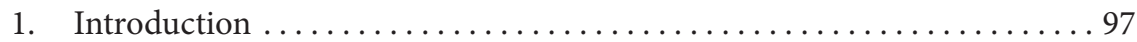


2. Migration in Hungary: The Status Quo.................... 98

2.1. Recent Developments in the Hungarian Regulation

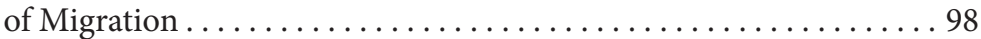

2.2. The Public Perception of Migrants in Hungary ............. . 99

2.3. Hungarian Legislation on Migration Closed the State's Borders De Facto and De Jure . . . . . . . . . . . . . . . . 101

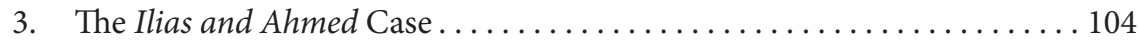

3.1. Violation of Article 3 ECHR ... . . . . . . . . . . . . . . . . . . . . . 104

3.2. Violation of Article 5 ECHR ........................ 106

4. Evaluation of the Implications of the Ilias and Ahmed Case . . . . . . . . . 107

5. Concluding Remarks ................................ 109

Annex: The National Consultation on Immigration and Terrorism ................................... 111

6. European Responses to the Mediterranean 'Refugee Crisis' and the Fear of Saving Lives (Invited Contribution)

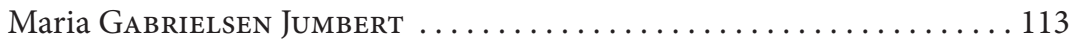

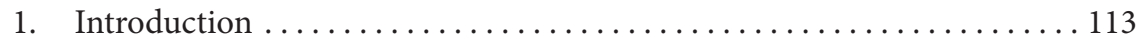

2. From Mare Nostrum to Triton: The Emergence of Maritime Rescue

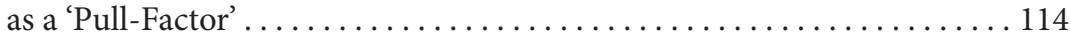

3. Examining the Data: Migrant Arrivals and Mortality............. 118

4. A Complex Debate Reduced to a Dilemma Regarding Whether or Not to Provide Humanitarian Aid . . . . . . . . . . . . . . . . . . 119

5. The 'Pull-Effect': Explaining the Otherwise Inexplicable . . . . . . . . 120

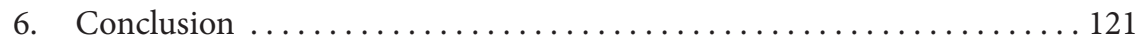

PART II

MIGRANTS, THEIR RIGHTS AND THE LIMITS THEREOF

7. Economic Refugees: An Analysis of the Phenomenon in the Context of the EU Migration Crisis

Agnieszka Piekutowska and Elżbieta Kużelewska . . . . . . . . . 125

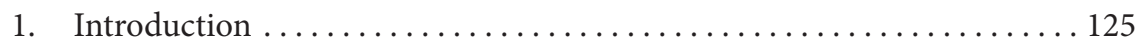

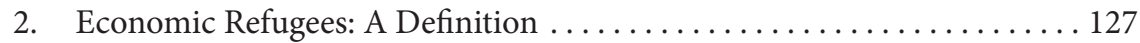

3. Economic Refugees: Poverty as a Cause and Barrier of International

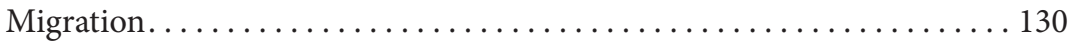

4. Economic Refugees in the Context of the EU Migration Crisis . . . . . . 133

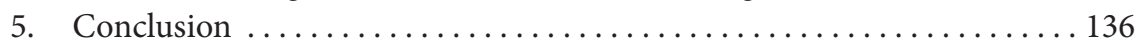


8. Defining the Offence of Migrant Smuggling: When the Migration Crisis Revives Old Debates

Chloé Brière . . . . . . . . . . . . . . . . . . . . . . . . . . . . . . . . . . . 139

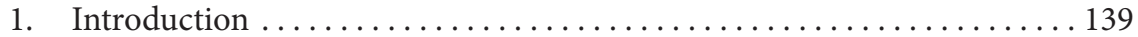

2. Difficulties in Elaborating a Common Definition of the Offence of Migrant Smuggling in EU Law . ...................... 143

2.1. Complex Negotiations ......................... 144

2.2. The Compromise Finally Reached .................. 147

2.3. A Need to Revise the Facilitators' Package?. . . . . . . . . . . . . . . 150

3. Impact of the Migration Crisis on the National Definitions of the Offence of Migrant Smuggling . . . . . . . . . . . . . . . 154

3.1. The Diversity of National Legislation . . . . . . . . . . . . . 155

3.2. Does the Refugee Crisis Impact on the Definition of the Offence at National Level? . . . . . . . . . . . . . . . . . . . . . . . . 159

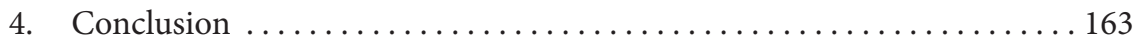

9. The Collapse of the Political Offence Exemption in EU Extradition Law: The End of Political Asylum?

Sibel Top ...................................... 165

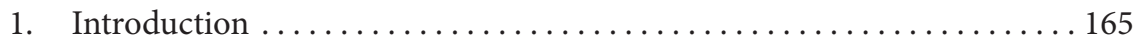

2. The Evolution of the Protection Associated with Political Crimes in European Extradition Law . . . . . . . . . . . . . . . . . . . . 167

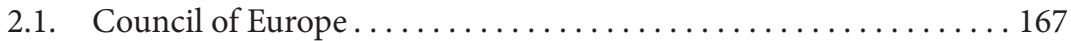

2.2. European Union ............................ 169

3. The Ambiguous Relationship Between Political Crimes and Terrorism . . . 172

3.1. The Difficulty in Defining Political Crimes ............. 172

3.2. The Difficulty in Distinguishing Political Crimes from Terrorism ............................ 173

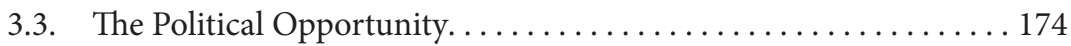

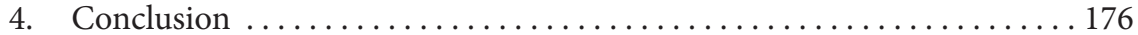

PART III

THE STATUS QUO OF MIGRATION IN EUROPE: SELECTED NATIONAL PERSPECTIVES

10. The Governance of the Migrant Crisis in Italy (Invited Contribution) Lino PANzeri . . . . . . . . . . . . . . . . . . . . . . . . . . . . . 181

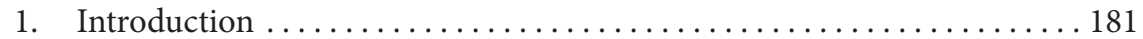

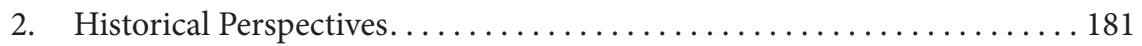

3. The Explosion of the 2011 Migrant Crisis. . . . . . . . . . . . . . . 185

4. Open Issues . . . . . . . . . . . . . . . . . . . . . . . 189 
11. The Impact of the Migration Crisis on Polish Immigration and Criminal Law

Magdalena Perkowska............................... 191

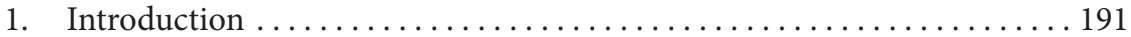

2. Illegal Migration to Poland . . . . . . . . . . . . . . . . . . . 192

3. Scale of Criminality Attributable to Foreigners in Poland ........... 206

4. Amendments Introduced into Polish Immigration and Criminal Law

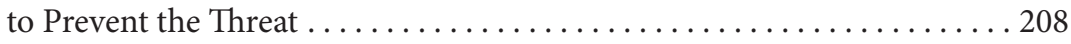

5. Conclusion ..................................... 223

12. The Role of NGOs as Partners in Migration Management in Estonia: A Case Study

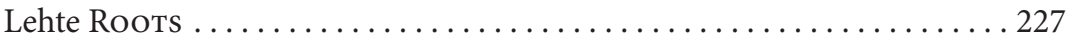

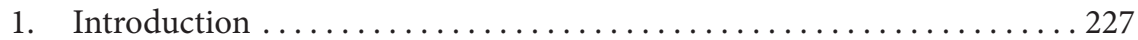

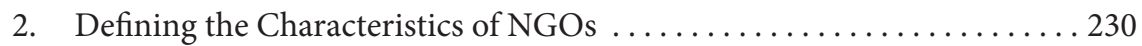

3. The Participation of NGOs in Policy-Making $\ldots \ldots \ldots \ldots \ldots \ldots \ldots 232$

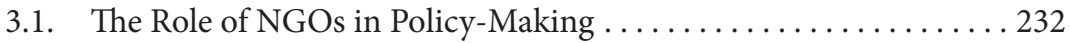

3.2. Assessing the Effectiveness of the Involvement of NGOs

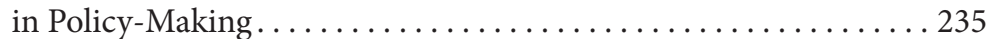

4. The Role of NGOs in Asylum Policy-Making in Europe . . . . . . . . . . 238

5. The Role of NGOs in Asylum Policy-Making in Estonia . . . . . . . . . . . . . . 242

5.1. Asylum and Refugee NGOs in Estonia . . . . . . . . . . . . . 242

5.2. The Participation of NGOs in Estonian Asylum Policy

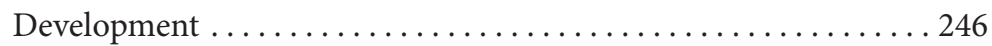

5.2.1. The Involvement of NGOs in the Drafting Phase

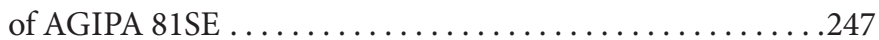

5.2.2. The Involvement of NGOs in the Parliamentary

Proceedings of AGIPA 81 SE ................. 248

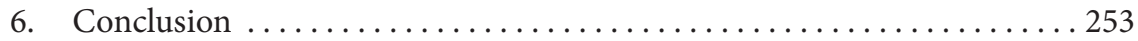

13. Linguistic Integration of Adult Migrants in the Era of the Migration Crisis

Halina Sierocka ... . . . . . . . . . . . . . . . . . . . . . . . 257

1. Introduction . . . . . . . . . . . . . . . . . . . . . . . . . . 257

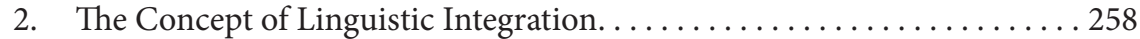

3. European Policies for the Linguistic Integration of Adult Migrants . . . . . 260

4. Language Policies for Migrants in EU Member States . . . . . . . . . . . 263

4.1. Language Requirements . . . . . . . . . . . . . . . . . . . 263

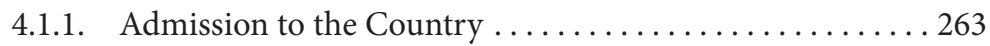

4.1.2. Language Requirements for Residence............... 264

4.1.3. Language Requirements for Citizenship ............. 264 
4.2. Developing Language Training for Adult Migrants ........... 265

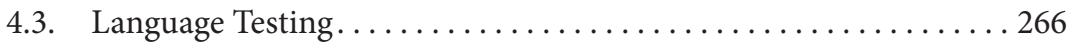

5. Discussion of Linguistic Integration in France, Germany and the United Kingdom ........................... 270

5.1. Language Policies for Adult Migrants ................. 271

5.1.1. Pre-entry Language Policies. ................ 271

5.1.2. Language Policies for Obtaining a Residence Permit. .... . 271

5.1.3. Language Policies for Obtaining Citizenship.......... 272

5.2. Integration Policies for Adult Migrants . . . . . . . . . . . . . 272

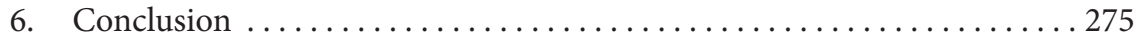




\section{LIST OF ABBREVIATIONS}

$\begin{array}{ll}\text { AA } & \text { Association Agreement } \\ \text { ABW } & \text { Agencja Bezpieczeństwa Wewnętrznego [Internal Security } \\ & \text { Agency] [Poland] } \\ \text { AFS } & \text { Area of Freedom, Security and Justice } \\ \text { AGIPA } & \text { Act on Granting International Protection to Aliens [Estonia] } \\ \text { AMIF } & \text { Asylum, Migration and Integration Fund [EU] } \\ \text { BIT } & \text { Bilateral Investment Treaty } \\ \text { CBP } & \text { Common Basic Principle } \\ \text { CEAS } & \text { Common European Asylum System } \\ \text { CEFR } & \text { Common European Framework of Reference for Languages } \\ \text { CFSP } & \text { Common Foreign and Security Policy } \\ \text { CIE } & \text { Identification and Expulsion Centre [Italy] } \\ \text { CISA } & \text { Convention implementing the Schengen Agreement } \\ \text { CJEU } & \text { Court of Justice of the European Union } \\ \text { CMR } & \text { Central Mediterranean Route } \\ \text { COMPAS } & \text { Centre on Migration, Policy and Society } \\ \text { CPA } & \text { Criminal Procedure Act [Hungary] } \\ \text { CPTA } & \text { Centre for Temporary Residence and Assistance [Italy] } \\ \text { CPT } & \text { European Committee for the Prevention of Torture and Inhuman } \\ & \text { or Degrading Treatment or Punishment } \\ \text { CSDP } & \text { Common Security and Defence Policy } \\ \text { DARIO } & \text { Draft Articles on Responsibility of International Organizations } \\ \text { DG } & \text { Directorate-General [European Commission] } \\ \text { EASO } & \text { European Asylum Support Office } \\ \text { EAW } & \text { European Arrest Warrant } \\ \text { EC } & \text { European Commission; European Community } \\ \text { ECB } & \text { European Central Bank } \\ \text { ECHR } & \text { European Convention on Human Rights } \\ \text { ECI } & \text { European Citizens' Initiative } \\ \text { ECRE } & \text { European Council on Refugees and Exiles } \\ \text { ECSC } & \text { European Coal and Steel Community } \\ \text { ECtHR } & \text { European Court of Human Rights } \\ & \text { European Defence Agency } \\ \text { EDAropean Economic Area } \\ \text { European External Action Service }\end{array}$




\begin{tabular}{|c|c|}
\hline EEC & European Economic Community \\
\hline EFSF & European Financial Stability Facility \\
\hline EFSM & European Financial Stabilisation Mechanism \\
\hline EHRC & Estonian Human Rights Centre \\
\hline EIO & European Investigation Order \\
\hline EMU & Economic and Monetary Union \\
\hline ENP & European Neighbourhood Policy \\
\hline ERC & Estonian Refugee Council \\
\hline ERF & European Refugee Fund \\
\hline ESM & European Stability Mechanism \\
\hline ESMA & European Securities and Markets Authorities \\
\hline EU & European Union \\
\hline EUBAM & EU Border Assistance Mission in Libya \\
\hline EUMC & EU Military Committee \\
\hline FRA & European Union Agency for Fundamental Rights \\
\hline Frontex & Frontières extérieures, European Border and Coast Guard Agency \\
\hline GATT & General Agreement on Tariffs and Trade \\
\hline ICJ & International Court of Justice \\
\hline ICT & Information and Communications Technologies \\
\hline IGC & Intergovernmental Conference \\
\hline ILC & International Law Commission \\
\hline ILO & International Labour Organization \\
\hline IMO & International Maritime Organization \\
\hline IOM & International Organization for Migration \\
\hline JHA & Justice and Home Affairs \\
\hline JMC & Johannes Mihkelson Centre \\
\hline KFOR & Kosovo Force \\
\hline LIAM & Linguistic Integration of Adult Migrants \\
\hline LIBE & $\begin{array}{l}\text { Committee on Civil Liberties, Justice and Home Affairs } \\
\text { [European Parliament] }\end{array}$ \\
\hline MEP & Member of the European Parliament \\
\hline MIPEX & Migrant Integration Policy Index \\
\hline MSF & Médecins Sans Frontières \\
\hline NATO & North Atlantic Treaty Organization \\
\hline NGO & Non-governmental Organisation \\
\hline OECD & Organisation for Economic Co-operation and Development \\
\hline PPU & $\begin{array}{l}\text { Procédure Préjudicielle d’Urgence [Urgent Preliminary Ruling } \\
\text { Procedure] }\end{array}$ \\
\hline PSC & Political and Security Committee of the EU \\
\hline RRO & Roundtable of Refugee Organisations \\
\hline SAR & Search and Rescue \\
\hline
\end{tabular}


SOLAS International Convention for the Safety of Life at Sea 1974

SPRAR Protection System for Asylum Seekers and Refugees

TEC Treaty Establishing the European Community

TEU Treaty on European Union

TFEU Treaty on the Functioning of the European Union

UK United Kingdom of Great Britain and Northern Ireland

UN United Nations

UNCLOS United Nations Convention on the Law of the Sea

UNHCR United Nations High Commissioner for Refugees

UNSC UN Security Council

UNTS United Nations Treaty Series 
